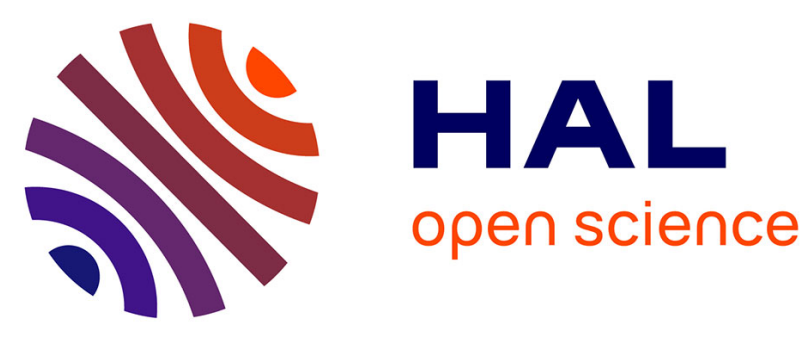

\title{
Precise dating of middle to late Villafranchian mammalian paleofaunae from the Upper Allier River valley (French Massif Central) using $\mathrm{U}-\mathrm{Pb}$ geochronology on volcanic zircons
}

Jean-Louis Paquette, Etienne Médard, Jean-Louis Poidevin, Pascal Barbet

\section{To cite this version:}

Jean-Louis Paquette, Etienne Médard, Jean-Louis Poidevin, Pascal Barbet. Precise dating of middle to late Villafranchian mammalian paleofaunae from the Upper Allier River valley (French Massif Central) using U-Pb geochronology on volcanic zircons. Quaternary Geochronology, 2021, 65, pp.101198. 10.1016/j.quageo.2021.101198 . hal-03243390

\author{
HAL Id: hal-03243390 \\ https://hal.uca.fr/hal-03243390
}

Submitted on 31 May 2021

HAL is a multi-disciplinary open access archive for the deposit and dissemination of scientific research documents, whether they are published or not. The documents may come from teaching and research institutions in France or abroad, or from public or private research centers.
L'archive ouverte pluridisciplinaire HAL, est destinée au dépôt et à la diffusion de documents scientifiques de niveau recherche, publiés ou non, émanant des établissements d'enseignement et de recherche français ou étrangers, des laboratoires publics ou privés.

\section{(ㅇ)(1) $\$$}

Distributed under a Creative Commons Attribution - NonCommercial - NoDerivatives 44.0 
Keywords: U-Pb geochronology; volcanic zircons; Villafranchian; mammals; paleofauna.

Abstract

The French Massif Central represents one of the rare occurrences in Europe where lower 16 Pleistocene fossil deposits are associated to a substantial volcanic activity. Thanks to the abundance of 17 volcanic zircons in the differentiated products of the Monts-Dore / Guéry stratovolcano, we were able 18 for the first time to use $\mathrm{U} / \mathrm{Pb}$ geochronology on zircon to precisely date lower Pleistocene fossil 19 deposits. Zircon, a weathering-proof heavy mineral, was dispersed over the landscape through Plinian eruptions, and quickly reworked in fossil-bearing sedimentary deposits. Five Villafranchian fossil sites in the Upper Allier River valley (French Massif Central) have been precisely dated: Chilhac 
MNQ18, $2.100 \pm 0.029 \mathrm{Ma}$, confirming the previously determined $2.18-2.10 \mathrm{Ma}{ }^{40} \mathrm{Ar} /{ }^{39} \mathrm{Ar}$ ages), Blassac-La Girondie (MNQ19, $1.946 \pm 0.029 \mathrm{Ma})$, and Vazeilles $(1.843 \pm 0.028 \mathrm{Ma})$. These new chronological data constrain the duration of the MNQ18 in central France to about $200 \mathrm{ka}$. The confirmation of an old age for the Blassac-La Girondie deposit indicates that the MNQ19 biozone started significantly earlier than previously thought.

\section{Introduction}

Recent evolution of megafaunae in Europe including human arrival is directly linked to ecological and climate variations over the last few million years (e.g., Kahlke et al. 2011, Palombo 2014). The Villafranchian mammal age, defined from fossil deposits at Villafranca d'Asti, Italy (Pareto 1865, Rook and Martínez-Navarro 2010) is a biochronological unit based on large mammal species that covers the key period between 3.5 and 1.0 Ma during which the current European fauna was established, including human migration to Europe, likely through the Caucasus region (e.g., Carbonell et al. 2008, Lordkipanidze et al. 2013). Within the Villafranchian, faunal evolution is characterized by the definition of lower level biozones, each transition between biozones being related to first appearance (FAD) or last occurrence (LAD) of key species. The most commonly used biochronological schemes for large European mammals in Europe are the Neogene and Quaternary Mammal zones (MNQ, Mein 1976; Guérin 1982; Guérin et al. 1990), and the Faunal Units (FU) (Azzarolli 1977, Palombo and Sardella 2007).

Biozones are, however, a tool that can only provide relative chronology (biochronology). Absolute chronology constraints are required to tie the faunal evolution to climate variations and compare faunal evolution from different places. The precise timing and duration of Western European mammal biozones is thus still poorly understood, due to the limited number of precise absolute chronological constraints. In this paper, we use zircon crystals to precisely date a series of Early to Middle Villafranchian deposits (MNQ17 to MNQ19 mammal biozones) from the Upper Allier River valley in 
central France. Zircon is a highly resistant, high-temperature mineral widely used to date magmatic and metamorphic formations, including silicic volcanic deposits. Compared to other minerals used by absolute geochronology techniques (feldspars, amphiboles, micas), zircon is preserved during weathering of volcanic deposits and subsequent transport and is reworked within secondary sedimentary deposits. Dating of volcanic zircons provide a minimum age for clastic sedimentary deposits, however, if transport processes are fast (cf. Pastre, 1987), the age of the sedimentary deposit will be within error of the age of the volcanic zircons. $\mathrm{U} / \mathrm{Pb}$ dating of volcanic zircons is thus an excellent tool for dating sedimentary fossil deposits, complementary to the more commonly used ${ }^{40} \mathrm{Ar} /{ }^{39} \mathrm{Ar}$ technique (e.g., Nomade et al. 2014b, 2016).

All the investigated Middle to Late Villafranchian faunae belong to the Gelasian age (2.588 to $1.806 \mathrm{Ma}$ ), the earliest part of the Pleistocene. In the French Massif Central, only three volcanic provinces were active during that time, the Devès volcanic field, the Escandorgue volcanic field, and the Mont-Dore / Guéry stratovolcano. The investigated sites are located on the northeastern edge of the Devès volcanic field, formed by a series of Plio-Pleistocene, mostly basanitic, eruptions that produced lava flows, strombolian scoria cones, phreatomagmatic maars and Surtseyan tuff-rings (Mergoil and Boivin 1993). A significant number of eruptions were dated by K/Ar geochronology (see compilation in Mergoil and Boivin 1993), and most of the current chronological constraints on the fossil sites comes from relative chronology between the fossiliferous sediments and the basanitic flows. The existing ages are however imprecise, with uncertainties of at least a few hundred thousand years. While the Devès volcanic field (as well as Escandorgue) exclusively emitted mafic lava, highly explosive, zircon-producing, silicic eruptions also occurred in the Mont-Dore / Guéry stratovolcano, $70 \mathrm{~km}$ to the northwest.

The Mont-Dore massif is a composite edifice formed by two stratovolcanoes (Baubron and Cantagrel, 1980; Nehlig et al., 2001), the Guéry and Sancy stratovolcanoes. The Guéry stratovolcano represents the oldest volcanic center, which emitted a large range of explosive volcanic products between 3.85 and 1.45 Ma (Cantagrel and Baubron, 1983; Pastre and Cantagrel, 2001; Nomade et al., 
2014a). The Sancy stratovolcano (1.1-0.25 Ma, Nomade et al. 2012) is younger than the deposits investigated here. Given the short distance, and the highly explosive activity of the Mont-Dore / Guéry stratovolcano, thin tephra layers likely blanketed the area during each Plinian eruption. Tephra-bearing

All ${ }^{40} \mathrm{Ar} /{ }^{39} \mathrm{Ar}$ ages from the literature cited in this paper have been recalculated assuming an age of 1.1891 Ma for the ACs standard (Niespolo et al. 2017) and using the Renne et al. (2011) decay constant, following the procedures described by Mercer et al. (2016). K/Ar ages were also corrected according to the decay constants of Renne et al. (2011) although changes are within the uncertainties. All uncertainties have been recalculated at the $2 \sigma$ level.

\section{Villafranchian fossil deposits in the Upper Allier River valley}

\subsection{Chilhac}

The Chilhac fossil sites are located NE of the village of Chilhac, in the Rabioulet valley, a small tributary of the Allier river. Fossils were first discovered in 1875 by de Morteuil (Boule 1892a, Bout 1960 ) in slope deposits, but the exact location of the discoveries (referred to as «Chilhac I») is unknown. Two fossiliferous sites were later excavated, Chilhac II on the right bank of the stream, and 
Chilhac II sediments are composed of non-bedded sandstones (containing angular basalt, quartz and gneiss pebbles) and slightly bedded clay- and mica-rich layers. Their exact depositional environment is still debated, and they have been interpreted as sediments from a slow-moving stream (Boivin et al., 2010), lacustrine sediments (Fouris et al. 1991), or lahar deposits (Pastre 1987). The Chilhac III deposits are partly disordered and are interpreted as the product of a landslide event affecting the Chilhac II sediments and overlaying pyroclastic and surface deposits (Boivin et al. 2010).

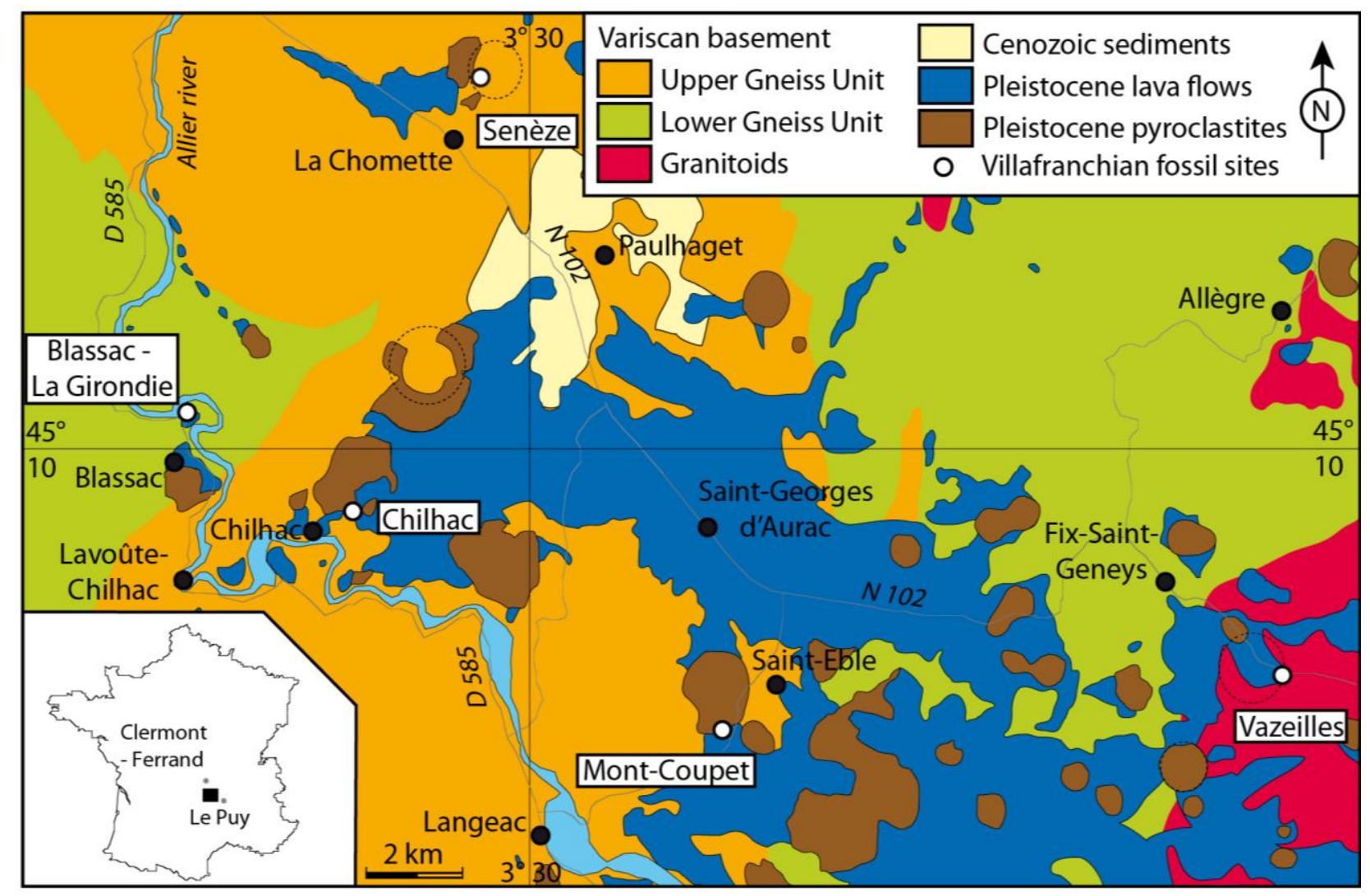

Figure 1. Simplified geological map of the investigated area, redrawn from BRGM 1/50 000 maps (Girod et al. 1979; Lasnier et al. 1981; Ledru et al. 1994; Marchand et al. 1986). The Paleozoic basement is partly covered by basanitic lava flows and pyroclasts belonging to the Devès volcanic field. Dashed circles are known maar structures, including the "Fressanges maar" (Vazeilles site, Séguy 1974) which was not known at the time the geological maps were drawn. Fossiliferous sites are contained within clastic sediments or slope deposits. 
The two sites produced nearly identical fauna (Table 1, Beden and Guth 1970a, Boeuf 1983) belonging to the MNQ17b biozone (Bøuf 1983, Palombo and Valli 2004). This fauna is more evolved than the Saint-Vallier fauna (MNQ17a reference site, Saint-Vallier Faunal Unit, Guérin 1982, Guérin et al. 2004, Palombo and Valli 2004), and is probably equivalent to the Coste San Giacomo Faunal Unit of Italy (Palombo and Valli 2004, Bellucci et al. 2014). Possible archeological artefacts (choppers) were found in the Chilhac III deposit (Guth 1974, Guth and Chavaillon 1985), but have been later proven to be natural artefacts (Reynal et al. 1995).

The ages of the Chilhac deposits have never been precisely constrained. Based on the faunal association (biostratigraphy), Bœuf (1997) favors an age close to 2.2 Ma. Both sites are arguably younger than the $2.50 \pm 0.12$ Ma Pié des Varennes basanitic lava flow (K/Ar age from Couthures and Pastre 1983), although the contact between the flow and the deposits is not visible (Boeuf 1997, Boivin et al. 2010).

The Chilhac II site is surmounted by the Sognes basanitic lava flow (Boivin et al. 2010), in turn covered by deposits from the Pié de Bouillergue scoria cone. K/Ar geochronology of the Sognes flow by three different laboratories gives ages of 1.67 Ma (no error reported), 1.88 Ma (no error reported), and 2.02 $\pm 0.60 \mathrm{Ma}$ (compilation in Boeuf 1983). The age of $1.67 \pm 0.10 \mathrm{Ma}$ (Couthures and Pastre 1983) is further constrained by a reverse magnetic polarity (Prévôt 1975) that would place it after the Olduvai subchron (i.e. younger than 1.780 Ma, Cohen and Gibbard 2019). More recently, a centimetric, possibly reworked, trachytic tephra layer intercalated within scoria deposits from the Pié de Bouillergue scoria cone, about $10 \mathrm{~m}$ above the top of the Chilhac fossil deposits, has been dated by ${ }^{40} \mathrm{Ar} /{ }^{39} \mathrm{Ar}$ at $2.34 \pm 0.08 \mathrm{Ma}$ (Nomade et al. 2014b). According to this age, the fossil deposits would be older than proposed by Boeuf (1997), between 2.50 and 2.34 Ma. We sampled sediments from the fossiliferous levels of Chilhac II (sample CH2 coming from the Chilhac IIb dig, Table 2) and Chilhac III (sample CH3), as well as the trachytic tephra layer previously dated by Nomade et al. (2014b) (sample CHR). 


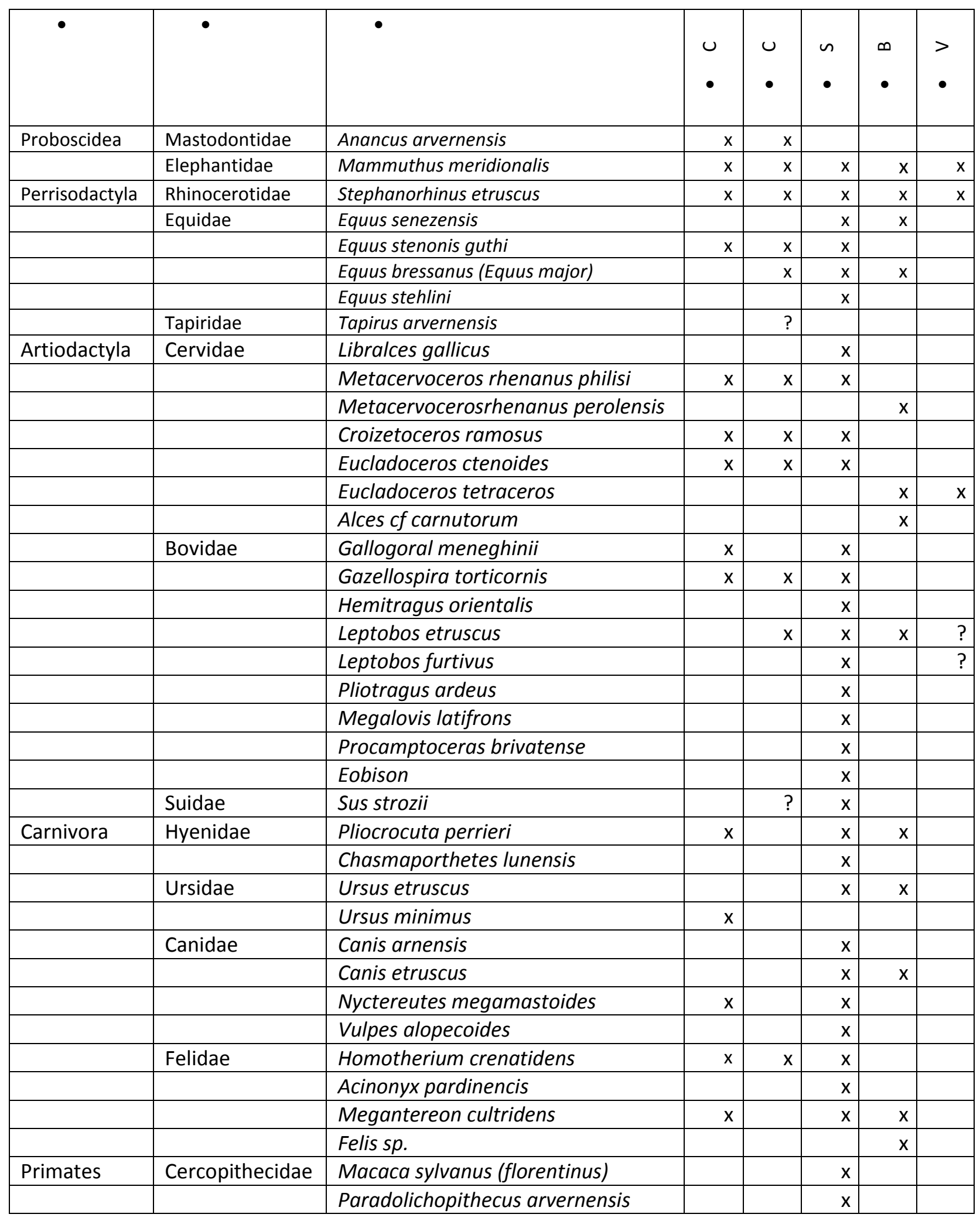

Table 1. Comparative list of large mammals described in the five investigated fossil deposits. The Chilhac list is reproduced from the compilation of Boivin et al. (2010), the Coupet list from Heintz 
The Mont Coupet is a monogenetic volcano belonging to the Devès volcanic field. An initial phreatomagmatic phase grades into a typical Strombolian scoria cone (Bout 1960). On the northern side, a basanitic lava flow emerges at the base of the scoria cone. On the southern flank of the volcano, weathered volcanic scoria forms a slope deposit up to 10-12 m thick (Dorlhac 1854, Bout 1960). This slope deposit contains bones and bone fragments (Dorlhac 1854). A basanitic lava flow originating from the neighboring Mont Briançon covers the lower part of the slope deposits (Bout 1970).

The Mont Coupet fossil deposit was discovered in 1849 (Aymard 1855). The fauna (Dorlhac 1854, Boule 1892a, Depéret et al. 1923, Heintz et al. 1974, Table 1) is very similar to the Chilhac fauna and belongs to the MNQ17b biozone (Palombo and Valli 2004).

The lava flow associated with the scoria cone has been dated by K/Ar at $2.14 \pm 0.18 \mathrm{Ma}$ (Fouris et al. 1991), providing an approximate upper limit for the age of the slope deposit. Bout (1970) reports a 1.9-1.8 Ma age for a lava flow from the neighboring Mont Briançon that covers the fossiliferous slope deposits. We directly sampled the fossiliferous slope deposits (sample COU) to provide stronger constraints on the age of this fossil site.

\subsection{Senèze}

The Senèze maar is a $500 \mathrm{~m}$ diameter phreatomagmatic crater belonging to the Devès volcanic field. The crater was later filled by at least $123 \mathrm{~m}$ of lacustrine sediments comprising a lower layer of sands (at least $43 \mathrm{~m}$ ) and an upper layer of clays (Ehlai 1969, Roger et al. 2000). The upper sedimentary layers are intercalated with and covered by slope deposits (Pastre et al. 2015).

The Senèze fossil deposits (Boule 1892b, Schaub 1943, Delson et al. 2006) are the reference locality for the MNQ18 biozone (Guérin 1982, 1990, 2007). The rich mammalian paleofauna was 
collected in the upper part of the lacustrine deposits and the associated slope deposits (Pastre et al. 2015).

The Lasnier basanitic flow, dated by K/Ar at $2.3 \pm 0.3 \mathrm{Ma}$ (Prévot 1975) or $2.55 \pm 0.12 \mathrm{Ma}$ (Couthures and Pastre 1983), is closely associated with the maar but does not fill it, placing an upper limit on the age of the phreatomagmatic eruption. A core drilled in the lacustrine sediments contained a $5 \mathrm{~cm}$ thick tephra layer at a depth of $20.75 \mathrm{~m}$ that has been dated by ${ }^{40} \mathrm{Ar} /{ }^{39} \mathrm{Ar}$ at $2.11 \pm 0.02 \mathrm{Ma}$ (Roger et al. 2000). Paleomagnetic data indicates that this tephra layer was deposited during the normal Réunion subchron, and since the $19 \mathrm{~m}$ upper part of the core show reverse polarity, it is younger than the end of the Réunion subchron at 2.116 Ma (Cohen and Gibbard 2019). This core is unfortunately disconnected from the fossil-bearing layers, but the fossil deposits are assumed to be the lateral equivalent of the upper part of the core, i.e. they would be younger than $2.11 \mathrm{Ma}$ (Pastre et al. 2015). During the latest excavations of the slope deposits, Pastre et al. (2015) identified several layers enriched in volcanic minerals and closely associated with the fossil deposits. In one trench, a layer located a few decimeters below the main fossiliferous bed (sample SEN1) inside interstratified lacustrine and slope deposits was dated by ${ }^{40} \mathrm{Ar} /{ }^{39} \mathrm{Ar}$ at $2.104 \pm 0.050 \mathrm{Ma}$ (Nomade et al. 2014b). A short normal polarity anomaly, likely corresponding to the Réunion subchron, has been found just above the dated layer (Sen in Nomade et al. 2014b), further supporting an age younger than $2.116 \mathrm{Ma}$ for the fossil deposit. In another of the recently excavated sites, fossiliferous lacustrine sediments were framed by two layers, below (SEN98) and above (SEN101), dated at $2.176 \pm 0.032 \mathrm{Ma}$ and $2.132 \pm$ $0.042 \mathrm{Ma}$, respectively (Nomade et al. 2014b). These ages are slightly older, but still consistent within error with the fossiliferous level of the first trench. Two other slope deposits disconnected from the fossiliferous layers were dated at $2.065 \pm 0.020 \mathrm{Ma}$ and 2.144 $\pm 0.044 \mathrm{Ma}$ (Nomade et al., 2014b). We sampled fossiliferous slope deposits on the edge of the crater (sample SEN), to put additional constraints on the youngest possible age of the fossil deposits. The sample comes from a series of alternating clays and sandy levels with centimetric pebbles, located less than $10 \mathrm{~m}$ from an outcrop of granitic basement. 


\subsection{Blassac-La Girondie}

The sedimentary sequence at Blassac-La Girondie crops out along the D585 road. It comprises

The Blassac fauna (Beden and Guth 1970b, Guth 1975) is younger than the MNQ18 fauna of Senèze and has been correlated with the MNQ19 fauna of Peyrolles, based on the presence of Cervidae remains similar to Metacervoceros perolensis (Beden and Guth 1970b, Heintz et al. 1974, Palombo and Valli 2004). This interpretation was later challenged by the attribution of the remains to another species, Metacervoceros rhenanus (Bœuf et al. 1992). Metacervoceros perolensis and Metacervoceros rhenanus might actually belong to the same species (de Vos et al. 1995). A cluster analysis performed by Palombo et al. (2006) indicates a very strong similarity between the Blassac-La Girondie and Peyrolles fauna. Other evidence for Blassac-La Girondie belonging to MNQ19 includes the association of Stephanorhinus etruscus and Eucladoceros tetraceros.

The basanitic flow overlying the fossil deposit has been dated by $\mathrm{K} / \mathrm{Ar}$ at $2.06 \pm 0.10 \mathrm{Ma}$ (Couthures and Pastre 1983) and 2.14 $\pm 0.12 \mathrm{Ma}$ (Fouris et al. 1991), placing a lower limit on the age of the Blassac-La Girondie fauna. A paleomagnetic study of the same flow gives a normal polarity (Prévot 1975), suggesting it erupted during either the Olduvai subchron (1.925 to 1.728 Ma, Cohen and Gibbard 2019), or the Réunion subchron (2.137 to 2.116 Ma, Cohen and Gibbard 2019). There is an ongoing controversy between the geochronology data suggesting an old age, and the 
paleontological data suggesting a correlation with the MNQ19 Peyrolles fauna that is assumed to be much younger $(1.449 \pm 0.024$; Nomade et al. 2014b). We sampled zircons from the fossiliferous level (sample BLA) to get a more precise age for this deposit.

\subsection{Vazeilles}

The Vazeilles deposit (also called Vazeilles-Limandre or Fix-Saint-Geneys) was discovered during construction work on the N102 road between Brioude and Le Puy-en-Velay in 1974 (Séguy 1974). A sequence of lacustrine sediments (Figure 2) fills the crater of a maar volcano ("Fressanges maar”) belonging to the Devès volcanic province (Séguy 1974; Fouris et al. 1991). The deposit is comprised mostly of layers of clay, silt, sand, gravel, and diatomite with a steep bedding plane (17 to 45-degree dip towards the west). At the top of the deposit, a clay layer is covered by a basanitic lava flow (Fouris et al. 1991).

Only a preliminary description of the paleofauna has been provided (Séguy, 1974): the sediments contained fossils of Stephanorhinus etruscus, a molar of Mammuthus meridionalis, a few bovidae bones (part of an astragalus and part of a tibia), and a molar from a large cervidae, possibly Eucladoceros.

The basanitic lava flow situated on top of the deposit has been dated by K/Ar at $1.31 \pm 0.12 \mathrm{Ma}$ (Fouris et al. 1991). The fossiliferous sediments have a normal magnetic polarity (Thouveny 1983), whereas the polarity around $1.31 \mathrm{Ma}$ was reverse (Matuyama chron). The youngest possible age for the sediments thus corresponds to the Olduvai subchron (1.925 to $1.780 \mathrm{Ma})$. We sampled a layer of gravel near the site were most fossils were discovered (sample VAZ1, Figure 2), and another sample at the top of the sedimentary sequence (VAZ2), 1 m below the basanitic lava flow dated by Fouris et al. (1991). 


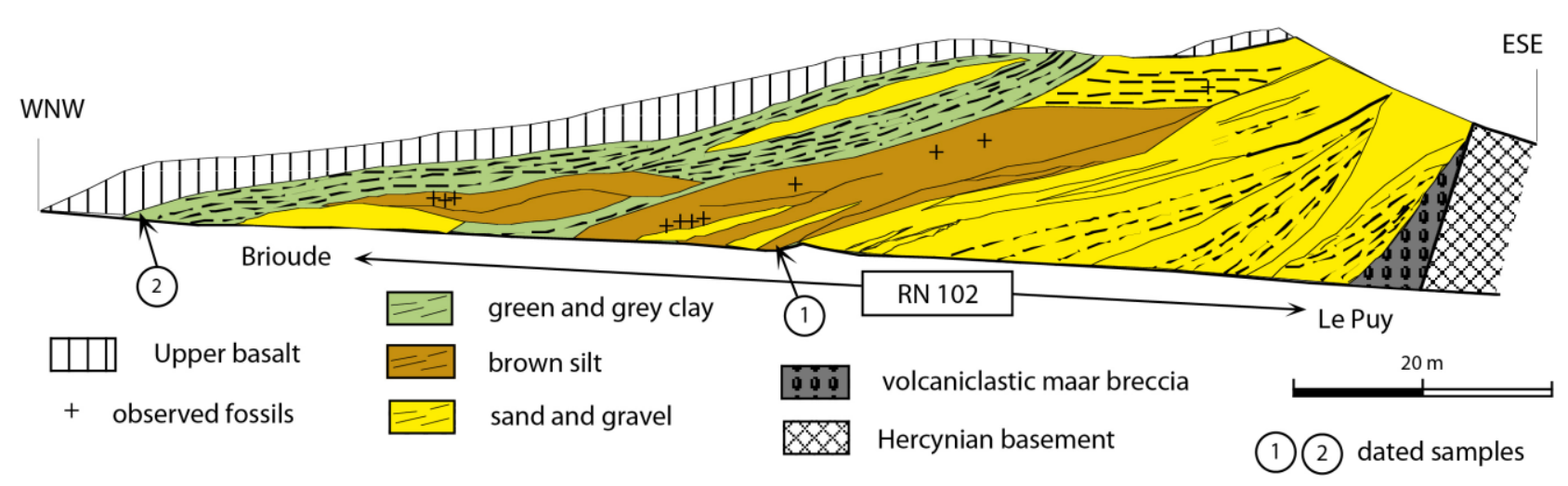

Figure 2. Cross-section of the Vazeilles deposits along the N102 road, redrawn from Séguy (1974).

\section{U-Pb geochronology}

\subsection{Analytical technique}

Between 1 and $10 \mathrm{~kg}$ of sediments were collected at each site. The sediment samples were cleaned and sieved, and zircons were separated from the $0.16-0.50 \mathrm{~mm}$ fraction by panning, magnetic separation and density separation using heavy liquids before handpicking under a binocular microscope. Zircons were then mounted in epoxy disks, ground, and polished with $0.25 \mu \mathrm{m}$ diamond grit to expose crystal interiors. U-Th-Pb isotopic data on zircons were obtained by laser ablation inductively coupled plasma mass spectrometry (LA-ICP-MS) at LMV (Laboratoire Magmas \& Volcans, Clermont-Ferrand, France). The analyses involved ablation of minerals with a Resonetics M50 laser system operating at a wavelength of $193 \mathrm{~nm}$. Spot diameters of $60 \mu \mathrm{m}$, repetition rates of $3 \mathrm{~Hz}$ and fluence of $3.0 \mathrm{~J} / \mathrm{cm}^{2}$ resulted in a spot depth of $12 \mu \mathrm{m}$ (details in Supplementary Table S1). The ablated material was carried into helium and then mixed with nitrogen (Paquette et al., 2014) and argon before injection into the plasma source of a Thermo Element XR Sector Field high-resolution ICP-MS equipped with the jet interface pumping device. The alignment of the instrument and mass calibration were performed before every analytical session using the NIST SRM 612 reference glass, by inspecting the signals of ${ }^{238} \mathrm{U},{ }^{232} \mathrm{Th}$ and ${ }^{208} \mathrm{~Pb}$ and by minimising the $\mathrm{ThO}^{+} / \mathrm{Th}^{+}$ratio. The analytical method for isotope dating with laser ablation ICP-MS is basically similar to that reported in Hurai et 
al. (2010) and Paquette et al. (2019). The ${ }^{235} \mathrm{U}$ signal is calculated from ${ }^{238} \mathrm{U}$ based on the ratio ${ }^{238} \mathrm{U} /{ }^{235} \mathrm{U}=137.818$ (Hiess et al., 2012). Single analyses consisted of 30 seconds of background integration with laser off followed by 60 seconds integration with the laser firing and a 30 seconds delay to wash out the previous sample and prepare the next analysis.

Data were corrected for $\mathrm{U}-\mathrm{Pb}$ fractionation occurring during laser sampling and for instrumental mass bias by standard bracketing with repeated measurements of GJ-1 zircon primary standard (Jackson et al., 2004). Repeated analyses of 91500 zircon reference material (Wiedenbeck et al., 1995) during each analytical session and treated as unknown, independently control the reproducibility and accuracy of the corrections. Data reduction was carried out with the software package GLITTER ${ }^{\circledR}$ from Macquarie Research Ltd (van Achterbergh et al., 2001; Jackson et al., 2004).

Schärer (1984) demonstrated that most zircons are affected during their growth by deficits and excesses of both ${ }^{230} \mathrm{Th}$ and ${ }^{231} \mathrm{~Pa}$ relative to the initial $\mathrm{Th} / \mathrm{U}$ secular equilibrium. In order to obtain accurate crystallization ages for young zircons $(<10 \mathrm{Ma})$, it is necessary to correct for the effect of initial disequilibria caused by intermediate nuclides in the ${ }^{238} \mathrm{U}$ and ${ }^{235} \mathrm{U}$ decay series. Sakata et al. (2017) and Sakata (2018) propose a simplified correction model and a related Microsoft Excel spreadsheet based on the mathematical framework of Wendt and Carl (1985) using the following equations:

$$
\begin{aligned}
& { }^{206} \mathrm{~Pb}^{*} /{ }^{238} \mathrm{U}=\left(e^{\lambda_{238} t}-1\right)+\lambda_{238} / \lambda_{230}\left(f_{\mathrm{Th} / \mathrm{U}}-1\right)\left(1-e^{-\lambda_{230} t}\right) e^{\lambda_{238} t} \\
& { }^{207} \mathrm{~Pb}^{*} /{ }^{235} \mathrm{U}=\left(e^{\lambda_{235} t}-1\right)+\lambda_{235} / \lambda_{231}\left(f_{\mathrm{Pa} / \mathrm{U}}-1\right)\left(1-e^{-\lambda_{231} t}\right) e^{\lambda_{235} t}
\end{aligned}
$$

The concentrations in $\mathrm{U}-\mathrm{Th}-\mathrm{Pb}$ are calibrated relative to the certified contents of GJ-1 zircon (Jackson et al., 2004) reference material. The available fractionation factor of $\mathrm{Pa} / \mathrm{U}$ in a zircon-melt system of rhyolitic composition roughly shows agreement with a value of $2.9 \pm 1.0$ (Sakata, 2018, Paquette et al., 2019). Owing to the lack of any available magmatic protolith for the zircon sources, an estimated $\mathrm{Th} / \mathrm{U}_{\text {melt }}$ value of 4.0 (Paquette et al., 2019) was systematically considered in the calculations as well as $50 \%$ uncertainties for the resulting individual $\left(\mathrm{Th} / \mathrm{U}_{\text {zircon }}\right) /\left(\mathrm{Th} / \mathrm{U}_{\text {melt }}\right)$ ratios. The isotopic 
ratios and $2 \sigma$ level uncertainties were corrected from elemental and isotopic fractionation, as well as $\mathrm{Pa} / \mathrm{U}$ and $\mathrm{Th} / \mathrm{U}$ disequilibria. A systematic external error is subsequently propagated by quadratic addition of uncertainties on $\mathrm{U}$ and Th decay constants as well as of the variability of the primary reference material used for corrections (GJ-1) and of the long term variability of the secondary reference material (91500). According to Horstwood et al. (2016), this systematic external error is added to the $2 \sigma$ error associated to the weighted mean ${ }^{206} \mathrm{~Pb} /{ }^{238} \mathrm{U}$ ages calculation. The Tera and Wasserburg (1972) diagrams were generated using Isoplot/Ex v. 2.49 software package by Ludwig (2001).

\section{2. $U-P b$ zircon results}

The investigated samples are either sediments or slope deposits, and zircons are reworked either from distal volcanic ash-falls, or from the local Variscan basement. Volcanic zircon crystals are light pink, most often euhedral and may contain undetermined translucent inclusions. Variscan grains are rather yellow with rounded shapes. The main analytical results are reported in Table 2.

\subsubsection{Chilhac fossil deposits}

For the Chilhac II sample, $\mathrm{U}$ and Th concentrations in the volcanic zircons are highly variable, from 58 to $1050 \mathrm{ppm}$ and from 39 to $5511 \mathrm{ppm}$, respectively. Th/U ratios are mostly higher than 1 up to values about 5. Sixty spots were performed on the zircon grains including 39 spots in Pliocene volcanic crystals and 21 spots in basement grains. A set of $34 \mathrm{Th} / \mathrm{U}$ disequilibria-corrected analyses yields a weighted mean ${ }^{206} \mathrm{~Pb} /{ }^{238} \mathrm{U}$ age of $2.285 \pm 0.046 \mathrm{Ma}$ (Fig. 3a), interpreted as the crystallization age of the zircons. Crystals from the basement range from Carboniferous to Neo-Proterozoic (Fig. 5) with one additional Neoarchean grain. 
In the Chilhac III sample, U (59 to $886 \mathrm{ppm}$ ) and Th (55 to $3906 \mathrm{ppm}$ ) contents as well as Th/U values (0.9 to 4.4$)$ are broadly similar than in the previous Chilhac II sample. The fifty-four laser spots were performed in 23 Pleistocene volcanic grains and 31 basement zircons. The volcanic zircons are divided into two populations; the 17 younger ones yield a $\mathrm{Th} / \mathrm{U}$ disequilibria-corrected mean ${ }^{206} \mathrm{~Pb} /{ }^{238} \mathrm{U}$ age of $2.262 \pm 0.057 \mathrm{Ma}$ (Fig. 4b), whereas six other zircons give an older mean ${ }^{206} \mathrm{~Pb} /{ }^{238} \mathrm{U}$ age of $2.53 \pm 0.10 \mathrm{Ma}$ (Fig. 4b). Finally, the basement crystals provide the same age ranges than in Chilhac II sample, from Carboniferous to Mesoarchean (Fig. 5a and b). The age of $2.26 \mathrm{Ma}$ is interpreted as the time of crystallization of the zircons in the magma chamber just preceding the volcanic eruption. The age of $2.53 \mathrm{Ma}$ could represent zircon grains related to an older unconstrained event, or may also be the effect of data scatter resulting from U-decay induced damaged zircon crystal parts. Even if this 2.53 Ma-old population mostly comprises low Th and U contents (<100 ppm), additional dating of thermally and chemically annealed zircon crystals would be required to solve this question (Von Quadt et al., 2014).

The upper trachytic airfall deposit contains only Neogene volcanic zircons for which the U (404 \pm $118 \mathrm{ppm})$ and Th contents $(419 \pm 220 \mathrm{ppm})$, as well as the Th/U ratios $(1.0 \pm 0.4)$ are more selfconsistent than in the two previous samples. Twenty-one of the twenty-three analysed laser spots yield a Th/U disequilibria-corrected mean ${ }^{206} \mathrm{~Pb} /{ }^{238} \mathrm{U}$ age of $1.727 \pm 0.028 \mathrm{Ma}$ (Fig. 4c). Interestingly, a single zircon crystal at $2.56 \mathrm{Ma}$ is synchronous within uncertainties with the older volcanic population of the Chilhac III sample dated at 2.53 Ma.

\subsubsection{Mont Coupet slope deposits}

In the Mont Coupet sample, the variable U (43 to $991 \mathrm{ppm})$ and Th (33-2483 ppm) contents are comparable to that of the Chilhac II and III samples. Similarly, Th/U ratios (0.7 to 3.1$)$ also display significantly high values. Thirty-nine of the forty-one spot analyses yield a Th/U disequilibriacorrected mean ${ }^{206} \mathrm{~Pb} /{ }^{238} \mathrm{U}$ age of $2.274 \pm 0.032 \mathrm{Ma}$ (Fig. 3d), which is also, within uncertainties, 
consistent with the ages measured on Chilhac II and III zircons. No other zircon crystals were recovered in that sample.
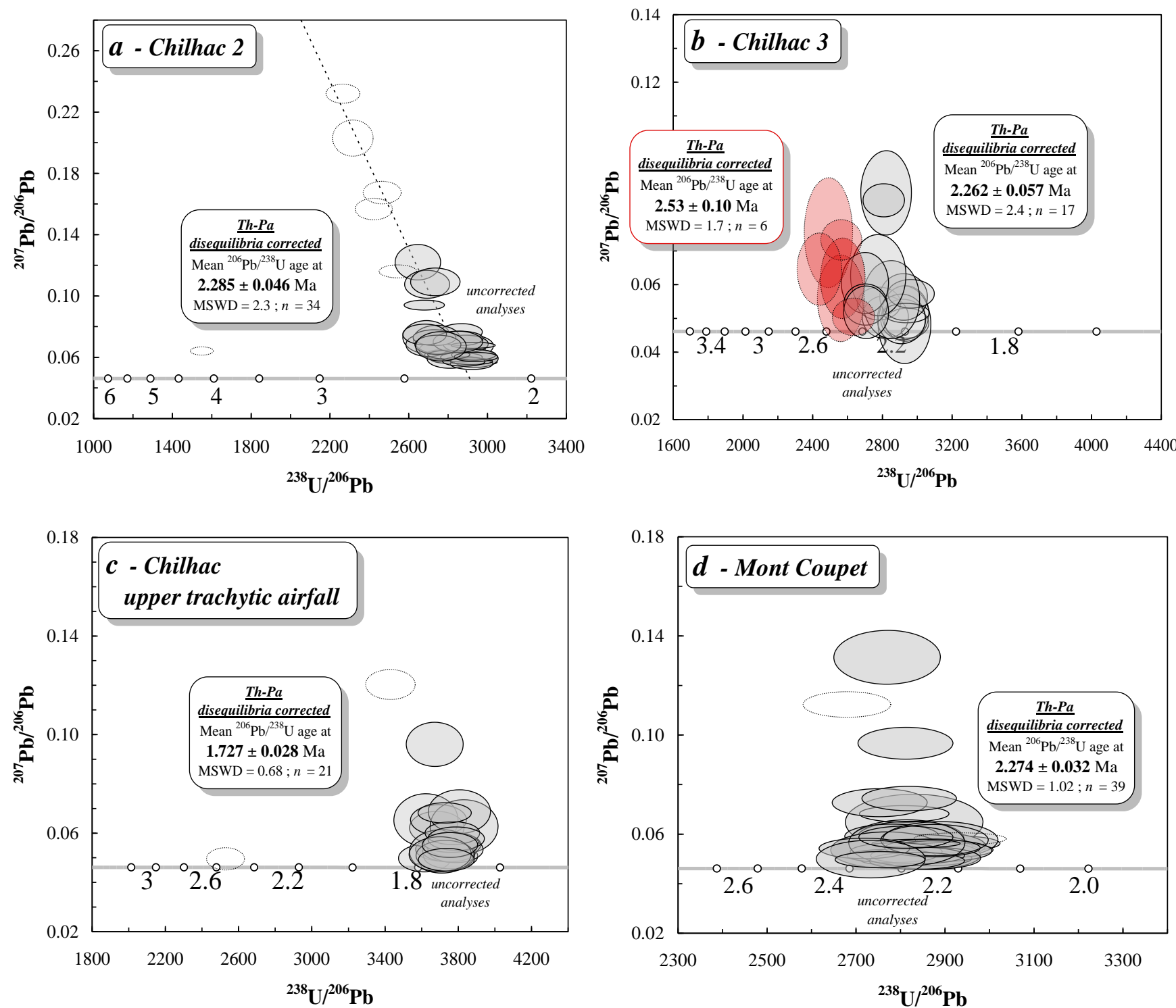

Figure 3. U/Pb diagrams for the investigated zircons from Chilhac and Mont Coupet fossils deposits. (a) and (b) are bulk sediments from the Chilhac deposits, $(c)$ is the upper trachytic airfall located $10 \mathrm{~m}$ above the Chilhac III deposit, and (d) are slope deposits from Mont Coupet.

\subsubsection{Senèze upper slope deposits}

In the Senèze sample, U (85-1103 ppm) and Th (71-2651 ppm) are still variable as well as Th/U ratios (0.7 to 2.7). Fifty-two spots were performed on Pleistocene volcanic zircons and yield a $\mathrm{Th} / \mathrm{U}$ 
347 disequilibria-corrected mean ${ }^{206} \mathrm{~Pb} /{ }^{238} \mathrm{U}$ age of $2.100 \pm 0.029 \mathrm{Ma}$ (Fig. 4a). Again, no basement zircons 348 were recovered in that sample.

\subsubsection{Blassac-La Girondie sand}

In the Blassac-La Girondie zircon crystals, U (59-450 ppm) and Th (45-542 ppm) contents are lower than in the other samples and associated with rather constant $\mathrm{Th} / \mathrm{U}(1.1 \pm 0.4)$ values. Twentyfive of the twenty-nine spots performed on the Pleistocene volcanic zircons yield a Th/U disequilibriacorrected mean ${ }^{206} \mathrm{~Pb} /{ }^{238} \mathrm{U}$ age of $1.946 \pm 0.029 \mathrm{Ma}$ (Fig. 4b). Eight basement zircons consistent with the age range defined by the Chilhac samples (Fig. 5a and b) have been analysed.

\subsubsection{Vazeilles sediments}

In the zircon crystals from the Vazeilles fossiliferous sediments, the U (93-796 ppm) and Th (1031808 ppm) contents are high and comparable to those of Chilhac and Le Coupet samples with varied igneous Th/U values (0.6-2.6). On the thirty-nine analyzed Pleistocene zircons, thirty-four grains yield a Th/U disequilibria-corrected mean ${ }^{206} \mathrm{~Pb} /{ }^{238} \mathrm{U}$ age of $1.843 \pm 0.028 \mathrm{Ma}$ (Fig. 4c). The five older zircon crystals range between $320 \mathrm{Ma}$ and $670 \mathrm{Ma}$.

In the Upper Level sample, the U (37-1077 ppm) and Th (51-2854) as well as Th/U ratios (0.72.6) display varied and high values, similarly to the former sample. A large group of 42 on 46 analyses yields a Th/U disequilibria-corrected mean ${ }^{206} \mathrm{~Pb} /{ }^{238} \mathrm{U}$ age of $1.648 \pm 0.025 \mathrm{Ma}$ (Fig. 4d). The three remaining zircon grains recorded ages of 580, 610 and 640 Ma, respectively (Fig. 5a). 

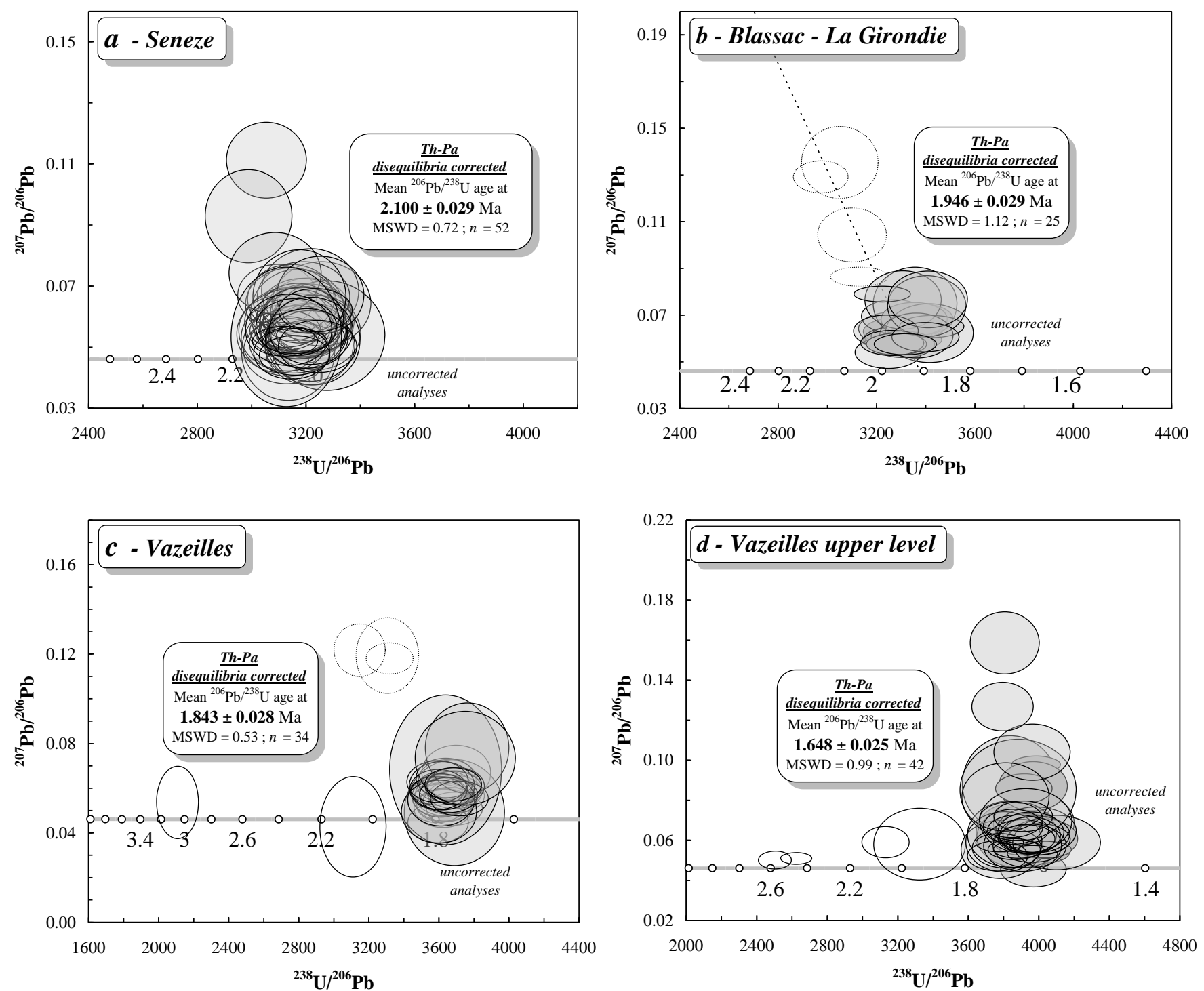

Figure 4. U/Pb diagrams for the investigated zircons from Senèze, Blassac-La Girondie and Vazeilles fossils deposits.

\subsubsection{Older zircons from the Variscan basement}

Sixty-eight zircons from the Chilhac II and III, as well as Blassac-La Girondie and Vazeilles samples are derived from the crystalline basement of the French Massif Central (Figure 5) and were either associated with the Neogene volcanic zircons during the volcanic eruptions or have been incorporated as detrital grains by late sedimentary processes. About half of this population (Figure 5b) defines a sharp Cambro-Ordovician ( 480 Ma) peak, whereas a subordinate Carboniferous peak most probably records the crystallization of Hercynian granites. The Cambro-Ordovician ages are typical of 
the protoliths of the Variscan Upper Gneiss Unit (e.g. Chelle-Michou et al., 2017), which constitutes the basement of the Chilhac area, and crops out upstream of the Blassac deposits, strongly suggesting that these zircons are detrital. An Ediacaran peak associated to the occurrence of Cryogenian and Archean grains is typical of the detrital zircon record related to the geodynamic evolution of the north Gondwana margin (e.g. Couzinié et al., 2019).

\begin{tabular}{|l|c|c|c|c|c|}
\hline \multicolumn{1}{|c|}{ sample } & $\mathrm{X}$ & $\mathrm{Y}$ & $\mathrm{Z}$ & $\begin{array}{c}\text { Age } \\
(\mathrm{Ma})\end{array}$ & $\begin{array}{c}2 \sigma \text { error } \\
(\mathrm{Ma})\end{array}$ \\
\hline $\mathrm{CH} 2(\mathrm{II})$ & $45^{\circ} 09^{\prime} 33.3^{\prime \prime} \mathrm{N}$ & $3^{\circ} 26^{\prime} 37.2^{\prime \prime} \mathrm{E}$ & $550 \mathrm{~m}$ & 2.285 & 0.046 \\
\hline $\mathrm{CH} 3(\mathrm{III})$ & $45^{\circ} 09^{\prime} 36.6^{\prime} \mathrm{N}$ & $3^{\circ} 26^{\prime} 41.6^{\prime \prime} \mathrm{E}$ & $585 \mathrm{~m}$ & 2.262 & 0.057 \\
\hline CHR & $45^{\circ} 09^{\prime} 43.3^{\prime \prime} \mathrm{N}$ & $3^{\circ} 26^{\prime} 45.5^{\prime \prime} \mathrm{E}$ & $580 \mathrm{~m}$ & 1.727 & 0.028 \\
\hline COU & $45^{\circ} 07^{\prime} 12.7^{\prime \prime} \mathrm{N}$ & $3^{\circ} 32^{\prime} 39^{\prime} 8^{\prime \prime} \mathrm{E}$ & $615 \mathrm{~m}$ & 2.274 & 0.032 \\
\hline SEN & $45^{\circ} 14^{\prime} 23.6^{\prime \prime} \mathrm{N}$ & $3^{\circ} 28^{\prime} 57.9^{\prime \prime} \mathrm{E}$ & $630 \mathrm{~m}$ & 2.100 & 0.029 \\
\hline BLA & $45^{\circ} 10^{\prime} 41.2^{\prime \prime} \mathrm{N}$ & $3^{\circ} 24^{\prime} 08.1^{\prime \prime} \mathrm{E}$ & $490 \mathrm{~m}$ & 1.946 & 0.029 \\
\hline VAZ1 & $45^{\circ} 07^{\prime} 38.8^{\prime \prime} \mathrm{N}$ & $3^{\circ} 41^{\prime} 34.9^{\prime \prime} \mathrm{E}$ & $987 \mathrm{~m}$ & 1.843 & 0.028 \\
\hline VAZ2 & $45^{\circ} 07^{\prime} 56.8^{\prime \prime} \mathrm{N}$ & $3^{\circ} 41^{\prime} 26.3^{\prime \prime} \mathrm{E}$ & $1010 \mathrm{~m}$ & 1.648 & 0.025 \\
\hline
\end{tabular}

Table 2. Sample location and U/Pb chronological data for the investigated fossil sites.

\section{Discussion}

\subsection{Constraining the age of sedimentary and slope deposits with volcanic zircons}

Since the investigated zircons are reworked from distal volcanic ash-falls, we should expect one or more zircon populations, with the youngest population providing a lower age for the sedimentary deposit. Proximal slope deposits (our samples from Mont Coupet and Senèze), indeed contain one single population of volcanic zircons with a well-constrained magmatic age (Figure $3 \mathrm{~d}$ and $4 \mathrm{a}$ ). 

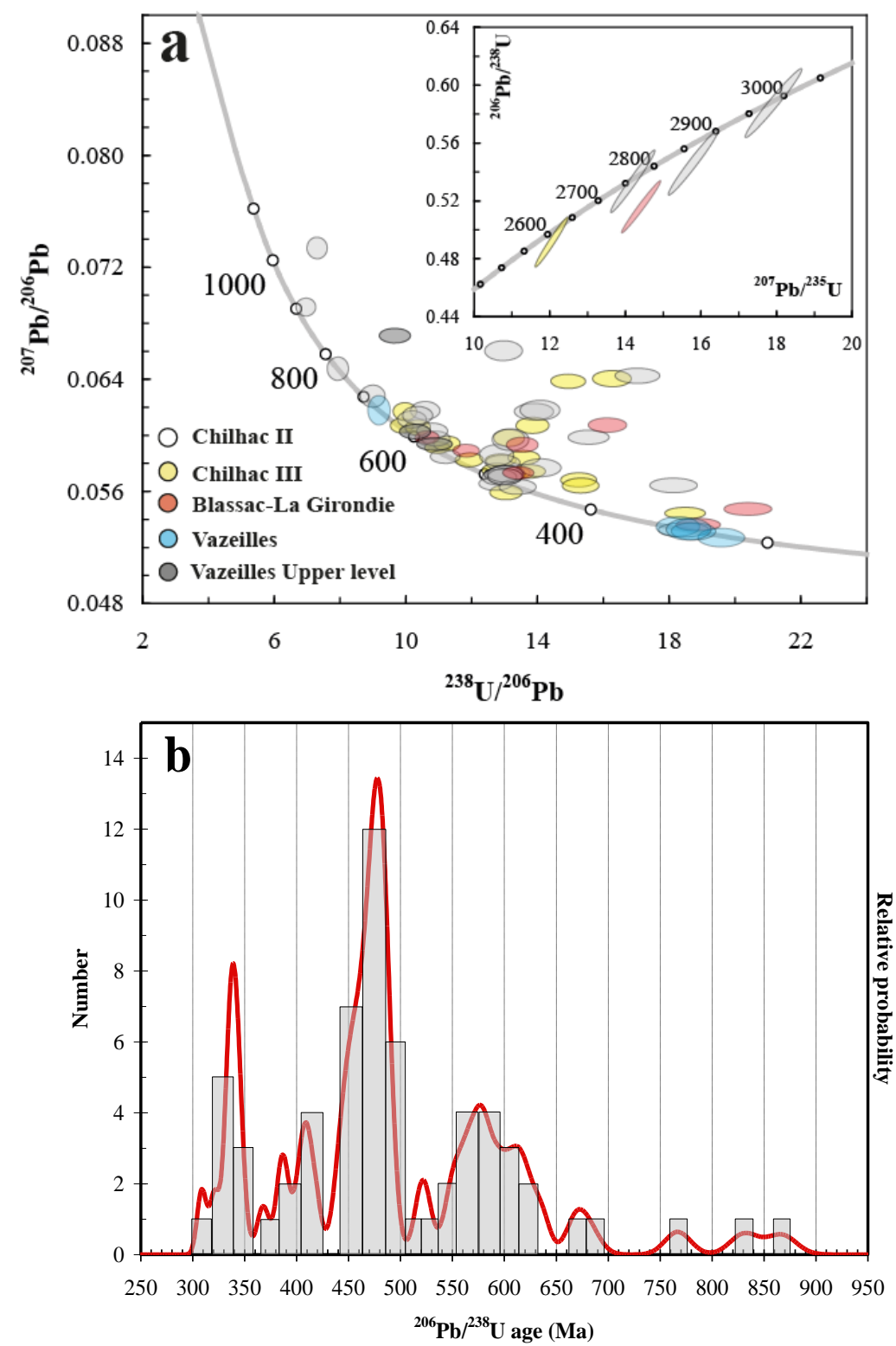

Figure 5. Older ages measured in pre-Cenozoic zircons from the fossiliferous sediments a) The Tera-

Wasserburg plot represents the Proterozoic and Phanerozoic ages; the Concordia diagram in inset shows the Archean ages; b) Cumulative probability ages histogram plot.

Sediments sampling a large, active, river basin (Allier river sediments at Blassac-La Girondie) still contain a dominant zircon population with a single magmatic age, and a small proportion of older zircons (volcanic and from the basement). A more complicated history emerges from the Chilhac deposits, which were formed in a small drainage system that eroded a variety of metamorphic and volcanic deposits. The zircon population is, however, still characterized by a predominance of the 
younger population age. These results confirm the conclusions of Pastre (1987) that heavy minerals deposited by airfalls are quickly reworked into the sedimentary network. Given this fast renewal, and a likely near-continuous volcanic activity from the Mont-Dore / Guéry stratovolcano, the highly dominant youngest zircon population in each sample provides an age very close to the deposition age of the sediment.

\subsection{New age constraints on major fossil deposits in volcanic context}

\subsubsection{Chilhac fossil deposits}

Zircons from both fossiliferous layers have statistically identical ages of $2.285 \pm 0.046 \mathrm{Ma}$ for Chilhac II and 2.262 \pm 0.057 Ma for Chilhac III, in agreement with the 2.2 Ma age proposed by Bœuf (1997) based on the biochronological attribution to the MNQ17b biozone. Although no proximal pyroclastic layer has been precisely dated in the Mont-Dore / Guéry stratovolcano between $2.5 \mathrm{Ma}$ (debris avalanches and lahars of the Perrier Plateau) and 2.07 Ma (Guéry tephra, Nomade et al. 2014a), relative chronology of trachytic pyroclastic deposits in the Vendeix stream and the Bouay waterfall sections indicate ages close to 2.3 Ma (Pastre and Cantagrel, 2001). These 2.27 Ma old zircons are thus interpreted as products of a Plinian eruption whose deposits are present but have not yet been precisely dated in the central part of the stratovolcano.

For the Chilhac samples, the number of old zircons is high (21/60 for Chilhac II, 31/54 for Chilhac III), pointing to a significant sedimentary component from the metamorphic basement, in agreement with the abundance of quartz and micas in the sediments. The Chilhac III sample also contains a significant amount of reworked volcanic zircons crystals (2.53 Ma).

Nomade et al. (2014b) dated a trachytic tephra located stratigraphically above the Chilhac III deposits by $\mathrm{Ar} / \mathrm{Ar}$ and obtained an age of $2.34 \pm 0.08 \mathrm{Ma}$, which would thus be a minimum age for the deposit. However, zircon $\mathrm{U} / \mathrm{Pb}$ ages for this deposit are significantly younger $(1.727 \pm 0.028 \mathrm{Ma})$, suggesting that the feldspars dated by Ar/Ar might be xenocrysts older than the trachytic layer. This is 
not uncommon and has been already described in the Monts-Dore for the "Grande Nappe » pyroclastic unit (Nomade et al. 2017). Also, the presence of metamorphic garnet, a mineral not seen in the proximal Mont-Dore deposits but widespread in the basement rocks of the Chilhac area might suggest that this unit is not a pristine ash-fall deposit and has been reworked. Our new results date this pyroclastic unit, and thus also the age of the Pié de Bouillergue scoria cone in which the layer is intercalated at $1.727 \pm 0.028 \mathrm{Ma}$. This age is consistent with the $\mathrm{K} / \mathrm{Ar}(1.67 \pm 0.10 \mathrm{Ma}$, Couthures et Pastre 1983) and paleomagnetic (< 1.78 Ma, Prévôt 1975) age of the Sogne basanitic flow, and precisely constrains the age of the Pié de Bouillergue volcanic eruption. Once again, there are no known proximal pyroclastic deposits of that age in the Mont-Dore / Guéry stratovolcano, but no proof of an activity gap at that time either.

The new ages of $2.285 \pm 0.046 \mathrm{Ma}$ and $2.262 \pm 0.057 \mathrm{Ma}$, identical within error (average 2.27 Ma), are much more consistent with previous paleontological estimates (e.g., Bœuf et al. 1992) than the $>2.34 \mathrm{Ma}$ age proposed by Nomade et al. (2014b). They are in excellent agreement with the age of the similar Coste San Giacomo fauna of Italy (estimated at 1.95-2.2 Ma by Bellucci et al. 2014), confirming the equivalence of the MNQ17b biozone and the Coste San Giacomo Faunal Unit.

\subsubsection{Mont Coupet slope deposits}

The fossil deposits at Mont Coupet contain zircons with the exact same age as the Chilhac fossil sites, $2.274 \pm 0.032 \mathrm{Ma}$. They were thus deposited during the same time period, a finding consistent with the presence of a very similar paleofauna (Table 1). Heavy mineral contents in the Mont Coupet slope deposits are dominated by kaersutitic amphibole, magnetite and titanite, a mineralogy identical to that observed in the Chilhac samples, further supporting a common origin for the Plinian deposit that was reworked at both sites (same eruption or clustered eruptions belonging to the same eruptive phase). Our age is consistent with the $2.14 \pm 0.18 \mathrm{Ma}$ age of a basanitic lava flow associated with the Mount Coupet activity (Fouris et al., 1991), providing that the flow was emplaced during the older 
2.32-2.24 part of the age bracket since the fossil-bearing slope deposits must be younger than the volcanic activity. Together with Chilhac, Mont-Coupet is one of the last occurence of Anancus arvernensis (a forest-dwelling species), replaced by Mammuthus meridionalis (an open land species) in younger sites. Global cooling and the advent of glacial cycles starting at about $2.5 \mathrm{Ma}$ in Western Europe (e.g., Shackleton et al., 1984, Kahlke et al., 2011) resulted in the progressive disappearance of large forests, replaced by a more open landscape. The two biotopes still coexisted in the Chilhac and Coupet area around 2.27 Ma.

\subsubsection{Senèze fossil deposits}

The upper slope deposit sampled in this study is dated at $2.100 \pm 0.029 \mathrm{Ma}$, consistent with an age younger than $2.104 \pm 0.050$ Ma for some of the recent fossil finds (Nomade et al., 2014b). A second fossil layer dated between $2.176 \pm 0.032 \mathrm{Ma}$ and $2.132 \pm 0.042 \mathrm{Ma}$ by Nomade et al. (2014b), also provides consistent ages within errors. Whether these fossil layers were deposited at the same time, or indicate a longer duration for the deposition process, or two different faunae are present as suggested by Azzaoli et al. (1997), is beyond the scope of this study.

\subsubsection{Blassac-La Girondie sand}

The site of Blassac-La Girondie is the richest French fossil site of the MNQ19 period, and its age can put key constraints on the beginning of this biozone. Sediments collected inside the fossil deposit give an age of $1.946 \pm 0.029 \mathrm{Ma}$, in agreement with previous rough estimates based on the local geology (Bœuf et al. 1992). This new data, however, favors an old age for the beginning of the MNQ19, which would start much earlier than the younger 1.47 Ma age proposed for the Peyrolles MNQ 19 reference fossil deposit (Nomade et al. 2014b). The sedimentary zircons could possibly be tied to pyroclastic deposits from the central part of the Guéry stratovolcano (La Morangie tephra, dated 
at $1.92 \pm 0.04$ Ma by Féraud et al., 1990), however, a detailed correlation between distal sedimentary deposits and proximal units is beyond the scope of this study.

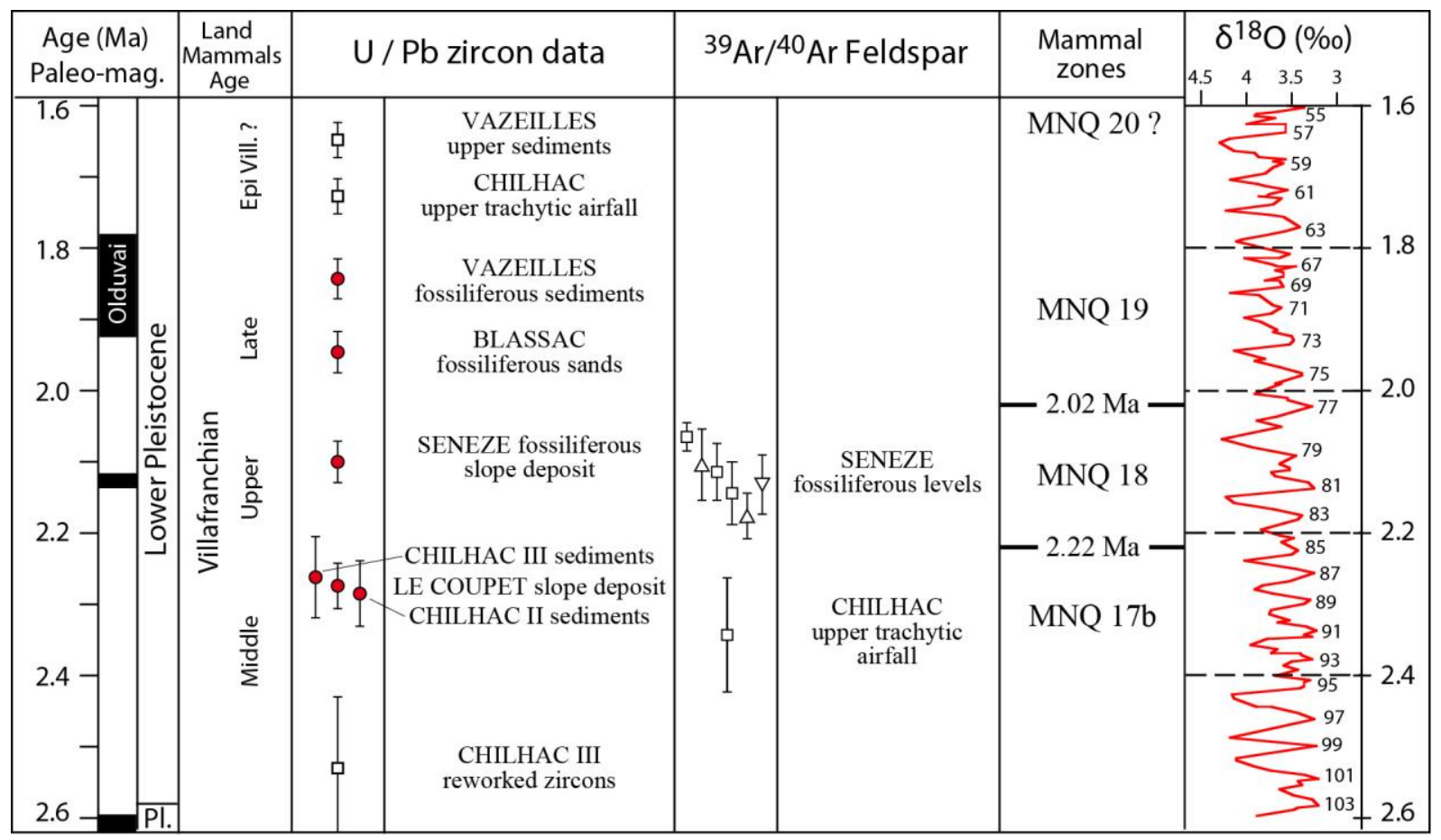

Figure 6: comparison of our new ages with existing ages for the Senèze and Chilhac deposits, European land mammal zones, paleomagnetic chrons, and oxygen isotope variations. U/Pb ages from this study, Ar/Ar ages from Nomade et al. (2014b) and Roger et al. (2000). Red circles are ages of fossiliferous sediments, white triangles ages of tephra-bearing layers above (down-pointing) or below (up-pointing) fossiliferous sediments, and squares for non-fossiliferous sediments or tephra-bearing layers disconnected from the fossil deposits.

\subsubsection{Vazeilles sediments}

The Vazeilles fossiliferous sediments, dated at $1.818 \pm 0.028 \mathrm{Ma}$, are slightly younger than the Blassac-La Girondie deposit. This age is consistent with the normal polarity of the sediments (Olduvai subchron between 1.925 and $1.780 \mathrm{Ma}$, Thouveny 1983). Only preliminary paleontological investigations have been performed on this site (Séguy 1974), however, the new age places this site 
firmly within the MNQ19 biozone. Given the paucity of fossil sites belonging to this time period in central France, this poorly known site is thus of significant interest for the understanding of faunal evolution during the late Villafranchian and would be worth further investigation. The sedimentary sequence could also provide a record of at least $200 \mathrm{ka}$ of geologic history since the top of the sequence has been dated around $1.648 \pm 0.025 \mathrm{Ma}$.

\subsection{Age constraints on late Villafranchian mammal biozones \\ 4.3.1. Duration of the MNQ18 biozone}

The new U-Pb zircon dating places further constraints on the age and duration of faunal biozones in Central France. The five investigated neighboring sites provide a $\sim 500 \mathrm{ka}$ record of land mammal evolution during the Middle Villafranchian (2.3-1.8 Ma), including significant faunal changes.

- The transition between biozones MNQ17b (latest site Chilhac III at $2.262 \pm 0.057 \mathrm{Ma}$ ) and MNQ18 (earliest possible age for the Senèze fossil deposits at $2.176 \pm 0.032 \mathrm{Ma}$, Nomade et al. 2014b) is precisely constrained at $2.22 \pm 0.09 \mathrm{Ma}$.

- The transition between biozones MNQ18 (latest fossiliferous level from Senèze at $2.100 \pm 0.029$ Ma) and MNQ19 (Blassac-La Girondie at $1.946 \pm 0.029 \mathrm{Ma}$ ) is precisely constrained at $2.02 \pm 0.10$ Ma.

These two boundaries are consistent with paleomagnetic constraints from the MNQ18 faunae Fonelas P-1 and Puebla de Valverde from Spain (Sinusìa et al. 2004, Arribas et al. 2009), which were deposited during the inverse polarity period separating the Réunion and Olduvai normal subchrons, i.e. between 2.116 and 1.925 Ma. They would also be consistent with a possible equivalence between MNQ18 and the Olivola F.U. of Italy dated around 2.10 $\pm 0.05 \mathrm{Ma}$ (Napoleone 2013), as suggested by Rook et al. (2010). 
The average duration of the MNQ18 biozone is $200 \mathrm{ka}$, with a maximum possible duration of 400ka, the maximum permissible time between the MNQ17b Chilhac III deposit $(2.262 \pm 0.057 \mathrm{Ma})$ and the MNQ19 Blassac-La Girondie deposit (1.946 $\pm 0.029 \mathrm{Ma})$.

\subsubsection{Age of the MNQ19 biozone}

Only a small number of fossil sites have been attributed to the MNQ19 biozone in Central France. Aside from the reference locality of Peyrolles (Heintz et al. 1974, Valli et al. 2006), the only sites are Blassac-La Girondie and La Sartanette (Palombo and Valli 2004). The age of the Peyrolles deposit has been estimated at $1.40 \pm 0.20 \mathrm{Ma}$ (Lo Bello 1988), and further refined at $1.449 \pm 0.024 \mathrm{Ma}$ (Nomade et al. 2014b) based on indirect evidence from neighboring pyroclastic deposits. Paleomagnetism data constrain the age of the sediments at La Sartanette to the Olduvai-Jaramillo inverse polarity interval (Thouveny et al. 1984), i.e. between 1.78 and 1.07 Ma. A statistical study by Palombo et al. (2006) confirms the similarity of the Peyrolles and Blassac-La Girondie fauna - La Sartanette was not included in their analysis.

The 1.946 $\pm 0.028 \mathrm{Ma}$ age of the Blassac-La Girondie site thus indicates that the MNQ19 biozone started much earlier than previously thought and solves the mystery of the absence of paleontological deposits in Central France between 2.1 and 1.5 Ma. However, existing ages for Blassac-la Girondie and Peyrolles, would suggest a very long duration for the MNQ19 biozone of about $500 \mathrm{ka}$. This period corresponds to at least two, possibly three Italian faunal units (Tasso F.U. dated around 1.7-1.8 Ma; Farneta F.U. dated around 1.6-1.7 Ma, and probably also Pirro F.U., Napoleone et al. 2013). This time period is still poorly known in Central France, and further research is needed to understand mammal evolution during the late Villafranchian.

\subsection{Implications for the tephrostratigraphy of the Mont-Dore stratovolcano}


The precise chronology of the Mont-Dore stratovolcano during the early Pleistocene is still poorly constrained. Following the major destructive stage that produced a series of four debris avalanches or debris flows (Bernard et al. 2009) at 2.6 Ma (Cantagrel and Briot 1990, Nomade et al. 2014b), Pastre and Cantagrel (2001) identified at least five major pyroclastic phases during their « middle trachytic cycle » (G3 and G4 cycles of Nomade et al. 2014a). The sites investigated in this study provide an excellent record of the distal tephrochronology of the Mont-Dore stratovolcano during that period and show the existence of at least nine distal tephra deposits that were reworked in the fossiliferous sediments $(2.53 \pm 0.10 \mathrm{Ma} ; 2.274 \pm 0.032 \mathrm{Ma} ; 2.176 \pm 0.032 \mathrm{Ma} ; 2.144 \pm 0.044 \mathrm{Ma} ; 2.100 \pm 0.029$ Ma; $1.946 \pm 0.029 \mathrm{Ma} ; 1.818 \pm 0.028 \mathrm{Ma} ; 1.727 \pm 0.025 \mathrm{Ma} ; 1.648 \pm 0.025 \mathrm{Ma}$ ). This list of nine different pyroclastic events capable of producing distal deposits $\sim 70 \mathrm{~km}$ from the Guéry stratovolcano is a conservative estimate since deposits with identical ages might represent different deposits with ages separated by a time shorter than the analytical uncertainty of the $\mathrm{U} / \mathrm{Pb}$ and ${ }^{40} \mathrm{Ar} /{ }^{39} \mathrm{Ar}$ dating techniques. Four of these pyroclastic events were previously unknown (2.27 Ma; $1.82 \mathrm{Ma} ; 1.73 \mathrm{Ma}$; 1.65 Ma). The three youngest ages fall within the 1.9 to $1.5 \mathrm{Ma}$ gap between the pyroclastic cycles III and IV of Nomade et al. (2014a) and confirms the observations of Pastre and Cantagrel (2001) of a rather continuous trachytic activity between 2.6 and $1.5 \mathrm{Ma}$.

\section{Conclusions}

Given the fast turnover of heavy mineral populations in sediments of the Upper Allier River basin, it is possible to precisely date fossil-bearing sedimentary deposits using $\mathrm{U} / \mathrm{Pb}$ ages on volcanic zircons originating from Plinian activity of the neighboring Mont-Dore / Guéry stratovolcano. We obtained volcanic zircons ages covering the entire Early Pleistocene, from 2.6 to $1.4 \mathrm{Ma}$, included during a possible activity gap between pyroclastic cycles III and IV of Nomade et al. (2014a). This indicates that there was no long-duration break in volcanic activity during the history of the volcano. 
Five paleontological deposits have been precisely dated using $\mathrm{U} / \mathrm{Pb}$ dating on volcanic zircons. 569 The new data reconciles biochronological and absolute ages for the Chilhac II deposit $(2.285 \pm 0.046$ $\mathrm{Ma})$ and a new precise age for Blassac-La Girondie (1.946 $\pm 0.029 \mathrm{Ma})$ indicates that the MNQ19 biozone started earlier than previously thought. These new U-Pb zircon dates place absolute constraints on the age and duration of the MNQ18 mammal biozone in Central France, and possibly by extension in Western Europe. Since the differentiated volcanic activity in the Mont-Dore area lasted at least from 3.85 to $0.25 \mathrm{Ma}$ (Nomade et al. 2014a), further analyses can be used to provide an absolute geochronological framework for MNQ mammal biozones defined in Central France.

\section{Acknowledgments}

The authors are grateful to Claire Fonquernie for her help with mineral separation. We warmly thanked the Doctors Luigi Solari, Albrecht von Quadt and an anonymous reviewer for their helpful corrections and comments as well as the editor Dr. Robyn Pickering for his great efficiency.

This research was supported by the French Government Laboratory of Excellence initiative ${ }^{\circ}$ ANR10-LABX-0006. This is Laboratory of Excellence ClerVolc contribution number 453.

\section{References}

Arribas, A., Garrido, G., Viseras, C., Soria, J.M., Pla, S., Solano, J.G., Garcés, M., Beamud, E., Carrión, J.S., 2009. A mammalian lost world in Southwest Europe during the late Pliocene. PLoS ONE 4(9), e7127.

Aymard, A., 1855. Communication sur la faune du Coupet. Annales de la Société d'Agriculture, Sciences, Arts et Commerce du Puy 20,30-36. 
Azzaroli, A., 1977. The Villafranchian stage in Italy and the Plio-Pleistocene boundary. In: Neogene-Quaternary Boundary Proceedings II Symposium, Bologna 1975, Giornale di Geologia (2) XLI, I-II, 61-79, Bologna.

Barbet, P., 2006. Approche taphonomique du site Pliocène terminal de Chilhac (Haute-Loire,

France) et étude paléontologique des Cervidae. PhD thesis, Muséum National d'Histoire Naturelle, Paris, $547 \mathrm{pp}$.

Baubron, J.-C., Cantagrel, J.-M., 1980. Les deux volcans des Monts-Dore (Massif Central Français). Comptes-Rendus de l'Académie des Sciences 290, 1409-1412.

Beden, M., Guth, C., 1970a. Nouvelles découvertes de restes de mammifères dans le gisement villafranchien de Chilhac (Haute-Loire). Comptes Rendus de l'Académie des Sciences, série D, 270, 2065-2067.

Beden, M., Guth, C., 1970b. Un nouveau gisement de vertébrés du Villafranchien de la vallée de l'Allier. Comptes Rendus de l'Académie des Sciences, série D, 271, 168-171.

Bellucci, L., Bona, F., Corrado, P., Magri, D., Mazzini, I., Parenti, F., Scardia, G., Sardella, R., 2014. Evidence of late Gelasian dispersal of African fauna at Coste San Giacomo (Anagni Basin, central Italy): Early Pleistocene environments and the background of early human occupation in Europe. Quaternary Science Reviews 96, 72-85.

Bernard, B., van Wyk de Vries, B., Leyrit, H., 2009. Distinguishing volcanic debris avalanche deposits from their reworked products: the Perrier sequence (French Massif Central). Bulletin of Volcanology 71, 1041-1056.

Bœuf, O., 1983. Le site Villafranchien de Chilhac (Haute-Loire) France. Etude paléontologique et biochronologique. PhD thesis, Paris VII University, 253 pp.

Bœuf, O., 1997. A propos de Chilhac, Senèze, Blassac-la-Girondie (Haute-Loire), gisements du Pliocène terminal, leur intérêt biochronologique. in Aguilar JP, Legendre S, Michaux J(Eds.), European Neogene Mammal Chronology, Actes du Congrès Biochrom'97. Mémoires et Travaux de l’Ecole Pratique des Hautes Etudes de Montpellier 21, 661-668. 
Bœuf, O., Geraads, D., Guth, C., 1992. Cervidés villafranchiens de Blassac-la-Girondie (HauteLoire, France). Annales de Paléontologie 78(3), 159-187.

Boivin, P., Barbet, P., Bœuf, O., Devouard, B., Besson, J.-C., Hénot, J.-M., Devidal, J.-L., Constantin, C., Charles, L., 2010. Geological setting of the lower Pleistocene fossil deposits of Chilhac (Haute-Loire, France). Quaternary International 223-224, 107-115.

Boule, M., 1892a. Description géologique du Velay. Bulletin des Services de la Carte géologique de la France 28, 1-259.

Boule, M., 1892b. Découverte d'un squelette d'Elephas meridionalis dans les cendres basaltiques du volcan de Senèze (Haute-Loire). Comptes Rendus Hebdomadaires des Séances de l'Académie des Sciences 115, 624-626.

Bout, P., 1960. Le Villafranchien du Velay et du bassin hydrographique supérieur et moyen de l'Allier, corrélations françaises et européennes. PhD Thesis, Imprimerie Jeanne d'Arc, Le Puy-enVelay, Haute-Loire, 344 pp.

Bout, P., 1970. Absolute ages of some volcanic formations in the Auvergne and Velay areas and chronology of the European Pleistocene. Palaeogeography Palaeoclimatology Palaeoecology 8, 95106.

Cantagrel, J.-M., Baubron, J.-C., 1983. Chronologie des éruptions dans le massif volcanique des Monts Dore (méthode potassium-argon), Implications volcanologiques. Géologie de la France 2, 123 142.

Cantagrel, J.-M., Briot, D., 1990. Avalanches et coulées de débris: le volcan du Guéry; où est la caldéra d'effondrement dans le Massif des Monts Dore? Comptes Rendus de l'Académie des Sciences Paris 311(II), 219-225.

Carbonell, E., Bermúdez de Castro, J.M., Parés, J.M., Pérez-González, A.,Cuenca-Bescós, G., Ollé, A., Mosquera, M., Huguet, R., van der Made, J., Rosas, A., Sala, R., Vallverdú, J., García, N., Granger, D.E., Martinón-Torres, M., Rodríguez, X.P., Stock, G.M., Vergès, J.M., Allué, E., Burjachs, 
F., Cáceres, I., Canals, A., Benito, A., Díez, C., Lozano, M., Mateos, A., Navazo, M., Rodríguez, J., Rosell, J., Arsuaga, J.L., 2008. The first hominin of Europe. Nature 452, 465-469.

Chelle-Michou, C., Laurent, O., Moyen, J.-F., Block, S., Paquette, J.-L., Couzinié, S., Gardien, V., Vanderhaeghe, O., Villaros, A., Zeh, A., 2017. Pre-Cadomian to late-Variscan odyssey of the eastern Massif Central, France: Formation of the West European crust in a nutshell. Gondwana Research 46, 170-190.

Cohen, K.M., Gibbard, P.L., 2019. Global chronostratigraphical correlation table for the last 2.7 million years, version 2019 QI-500. Quaternary International 500, 20-31.

Couthures, J., Pastre, J.-F., 1983. Chronostratigraphie du Plio-pléistocène d'Auvergne et du Velay: nouveaux apports des datations radiométriques et du paléomagnétisme. Bulletin de l'Association Française pour l'Etude du Quaternaire 1, 9-18.

Couzinié, S., Laurent, O., Chelle-Michou, C., Bouilhol, P., Paquette, J.-L., Gannoun, A.-M., Moyen, J.-F., 2019. Detrital zircon U-Pb-Hf systematics of Ediacaran metasediments from the French Massif Central: consequences for the crustal evolution of the north Gondwana margin. Precambrian Research 324, 269-284.

Debard, E., Pastre, J.-F., 2004. Le Maar de Senèze, géologie. in Pastre, J.-F. (Ed.), Quaternaire et Volcanisme en Auvergne et Velay, livret-guide de l'excursion AFEQ, mai 2004, pp. 102-108.

Delson, E., Faure, M., Guérin, C., Aprile, L., Blackwell, B.A.B., Debard, E., Harcourt-Smith, W., Martine-Suarez, E., Monguillon, A., Parenti, F., Pastre, J.-F., Sen, S., Skinner, A.R., Swisher III, C.C., Valli, A.M.F., 2006. Franco-American renewed research at the Late Villafranchian locality of Senèze (Haute-Loire, France). Cour. Forschungs-Institute Senckenberg 256, 275-290.

Depéret, C., Mayet, L., Roman, F., 1923. Les éléphants pliocènes. 1ère partie: Elephas planifrons Falconer des sables de Chagny et faunes de mammifères d'âge villafranchien Saint-Prestien. 2ème partie: monographie des éléphants pliocènes d'Europe et d'Afrique du Nord. Annales de l'Université de Lyon I, Sciences-Médecine, fasc. 42. 
de Vos, J., Mol, D., Reumer, W.F., 1995. Early Pleistocene cervidae (Mammalia, Artyodactyla)

from the Oosterschelde (the Netherlands), with a revision of the cervid genus Eucladoceros Falconer, 1868. Deinsea, 2, 21-95.

Dorlhac, M.J., 1854. Notice sur le cratère de Coupet et sur son gisement de gemmes et d'ossements fossiles. Annales de la Société d'Agriculture, Sciences, Arts et Commerce du Puy 19, 497517.

Elhaï, H., 1969. La flore sporo-pollinique du gisement villafranchien de Senèze (Massif central, France). Pollen et Spores 11(1), 127-139.

Féraud, G., Lo Bello, P., Hall, C.M., Cantagrel, J.-M., York, D., Bernat, M., 1990. Direct dating of Plio-Quaternary pumices by ${ }^{40} \mathrm{Ar} /{ }^{39} \mathrm{Ar}$ step-heating and single-grain laser fusion methods: the example of the Monts-Dore massif (Massif Central, France) Journal of Volcanology and Geothermal Research 40, 39-53.

Fouris, M., Cantagrel, J.M., Poidevin, J.L., Mergoil, J., 1991. Le Plio-pléistocène du Velay: volcanologie et chronologie K/Ar des gisements fossilifères. Données actuelles, problèmes et hypothèses. in Datation et caractérisation des milieux Pléistocènes. Actes des symposiums 11 et 17 de la 11ème Réunion Annuelle des Sciences de la Terre, Clermont-Ferrand, 1986. Cahiers du Quaternaire $16,401-416$.

Garcés, M., Agustí, J., Parés, J.M., 1997. Late Pliocene continental magnetochronology from the Guadix-Baza Basin (Betic Ranges, Spain). Earth Planet. Sci. Lett. 146(3-4), 677-688.

Girod, M., Bouiller, R., Weber, F., Larqué, P., Giot, D., 1979. Geological map of France (1/50,000), Le Puy en Velay sheet (791).Orléans: BRGM

Guérin, C., 1982. Première biozonation du Pléistocène européen, principal résultat biostratigraphique de l'étude des Rhinocerotidae (Mammalia, Perissodactyla) du Miocène terminal au Pléistocène supérieur d'Europe occidentale. Geobios 15(4), 593-598.

Guérin, C., 1990. Biozones or mammal units? Methods and limits in biochronology. In: Lindsay EH, Fahlbusch V, Mein P (Eds.), European Neogene Mammal Chronology. Plenum Press Edit., New 
York, (NATO Advanced Research Workshop “European Neogene Mammal Chronology” Munich, Mai 1988), 119-130.

Guérin, C., 2007. Biozonation continentale du Plio-pléistocène d'Europe et d'Asie occidentale par les mammifères: état de la question et incidence sur les limites Tertiaire/Quaternaire et Plio/Pléistocène. Quaternaire 18(1), 23-33.

Guérin, C., Faure, M., Argant, A., Argant, J., Crégut-Bonnoure, E., Debard, E., Delson, E., Eisenmann, V., Hugueney, M., Limondin-Lozouet, N., Martin-Sufirez, E., Mein, P., Mourer-Chauviré, C., Parenti, F., Pastre, J.-F., Sen, S., Valli, A.M.F., 2004. Le gisement pliocène supérieur de SaintVallier (Drôme, France) : synthèse biostratigraphique et paléoécologique. Geobios 37, S349-S360.

Guth, C., 1974. Découverte dans le Villafranchien d'Auvergne de galets aménagés. Comptes Rendus de l'Académie des Sciences Paris 279, 1071-1072.

Guth, C., 1975. Chilhac et Blassac-La Girondie, deux gisements Villafranchiens de la vallée de l'Allier. Colloque CNRS 218, 4-9 juin 1973: Problèmes actuels de paléontologie - Evolution des vertébrés, 627-630.

Guth, C., Chavaillon, J., 1985. Découverte en 1984 de nouveaux outils paléolithiques à Chilhac III (Haute-Loire). Bulletin de la Société Préhistorique Française 82, 56-64.

Heintz, E., Guérin, C., Martin, P., Prat, F., 1974. Principaux gisements Villafranchiens de France : listes fauniques et biostratigraphie. Mémoires du BRGM 78, 411-417.

Hiess, J., Condon, D.J., McLean, N., Noble, S.R., 2012. ${ }^{238} \mathrm{U} /{ }^{235} \mathrm{U}$ systematics in terrestrial uranium-bearing minerals. Science $335,1610-1614$.

Horstwood, M.S.A., Košler, J., Gehrels, G., Jackson, S., McLean, N., Paton, C., Pearson, N.J., Sircombe, K., Sylvester, P., Vermeesch, P., Bowring, J.F., Condon, D.J., Schoene, B., 2016. Community-derived standards for LA-ICP-MS U-(Th-)Pb geochronology - Uncertainty propagation, Age interpretation and data reporting. Geostandard and Geoanalytical Research, 40, 3, 311-332. 
Hurai, V., Paquette, J.-L., Huraiová, M., Konečný, P., 2010. U-Th-Pb geochronology of zircon and monazite from syenite and pincinite xenoliths in Pliocene alkali basalts of the intra-Carpathian back-arc basin. Journal of Volcanology and Geothermal Research 198, 275-287.

Jackson, S.E., Pearson, N.J., Griffin, W.L., Belousova, E.A., 2004. The application of laser ablation-inductively coupled plasma-mass spectrometry to in situ $\mathrm{U}-\mathrm{Pb}$ zircon geochronology. Chemical Geology 211, 47-69.

Jaffrey, A.H., Flynn, K.F., Glendenin, L.E., Bentley, W.C., Essling, A.M., 1971. Precision measurements of half-lives and specific activities of $U^{235}$ and $U^{238}$. Physical Reviews, C4, 1889.

Kahlke, R.D., García, N., Kostopoulos, D.S., Lacombat, F., Lister, A.M., Mazza, P.P.A., Spassov, N., Titov, V.V., 2011. Western Palaearctic palaeoenvironmental conditions during the Early and early Middle Pleistocene inferred from large mammal communities, and implications for hominin dispersal in Europe. Quaternary Science Reviews 30, 1368-1395.

Lasnier B., Marchand, J., Bouiller, R., Cornen, G., Burg, J.-P., Forestier, F.-H., Leyreloup, A., 1981. Geological map of France (1/50,000), Brioude sheet (766).Orléans: BRGM.

Ledru, P., Vitel, G., Beurrier, M., Marchand, J., Dallain, C., Turland, M., Etlicher, B., Dautria, J.M., Liotard, J.-M., 1994. Geological map of France (1/50,000), Craponne-sur-Arzon sheet (767). Orléans: BRGM.

Lo Bello, P., 1988. Géochronologie par la méthode ${ }^{39} \mathrm{Ar}-{ }^{40} \mathrm{Ar}$ de ponces quaternaires contaminées: exemple des ponces du Mont-Dore (Massif Central, France). Utilisation d'un laser continu pour la datation des minéraux individuels. PhD thesis, Université de Nice, 122 pp.

Lordkipanidze, D., Ponce de León, M.S., Margvelashvili, A., Rak, Y., Rightmire, G.P., Vekua, A., Zollikofer, C.P.E., 2013. A complete skull from Dmanisi, Georgia, and the evolutionary biology of Early Homo. Science 342(6156), 326-331.

Ludwig, K.R., 2001. User's manual for Isoplot/Ex Version 2.49, a Geochronological Toolkit for Microsoft EXCEL. Berkeley Geochronological Center, Special Publication 1a, Berkeley, USA (55 pp). 
Marchand, J., Bouiller, R., Cornen, G., Burg, J.-P., Lasnier B., 1986. Geological map of France (1/50,000), Langeac sheet (790). Orléans: BRGM.

Mein, P., 1976, Biozonation du Néogène méditerranéen à partir de mammifères. Proceedings VIth congress R.C.M.N.S., Bratislava 1975.

Mercer, C.M., Hodges, K.V., 2016. ArAR - A software tool to promote the robust comparison of $\mathrm{K}-\mathrm{Ar}$ and ${ }^{40} \mathrm{Ar} /{ }^{39} \mathrm{Ar}$ dates published using different decay, isotopic, and monitor-age parameters. Chemical Geology 440, 148-163.

Mergoil, J., Boivin, P., 1993. Le Velay. Son volcanisme et les formations associées. Géologie de la France 3, 1-96.

Mossand, P., Cantagrel, J.-M., Vincent, P., 1982. La caldera de Haute Dordogne: âge et limites (Massif des Monts-Dore, France). Bulletin de la Société Géologique de France 24(4),727-738.

Napoleone, G., Albianelli, A., Azzaroli, A., Bertini, A., Magi, M., Mazzini, M., 2003. Calibration of the upper Valdarno basin to the Plio-Pleistocene for correlating the Apennine continental sequences. Il Quaternario 16, 131-166.

Nehlig, P., Boivin, P., De Goër de Hervé, A., Mergoil, J., Prouteau, G., Thiéblemont, D., 2001. Les volcans du Massif central. Géologues 66-91.

Niespolo, E.M., Rutte, D., Deino, A.N., Renne, P.R., 2017. Intercalibration and age of the Alder Creek sanidine ${ }^{40} \mathrm{Ar} /{ }^{39} \mathrm{Ar}$ standard. Quaternary Geochronology 39, 205-213.

Nomade, S., Pastre, J.-F., Nehlig, P., Guillou, H., Scao, V., Scaillet, S., 2014a. Tephrochronology of the Mont-Dore volcanic Massif (Massif Central, France): new ${ }^{40} \mathrm{Ar} /{ }^{39} \mathrm{Ar}$ constraints on the late Pliocene and Early Pleistocene activity. Bull. Volcanol. 76(3), 1-17.

Nomade, S., Pastre, J.-F., Guillou, H., Faure, M., Guérin, C., Delson, E., Debard, E., Voinchet, P., Messager, E., 2014b. ${ }^{40} \mathrm{Ar} /{ }^{39} \mathrm{Ar}$ constraints on some French landmark Late Pliocene to Early Pleistocene large mammalian paleofaunas: Paleoenvironmental and paleoecological implications. Quaternary Geochronology 21, 2-15. 
Nomade, S., Pastre, J.-F., Pereira, A., Courtin-Nomade, A., Scao, V., 2017. New ${ }^{40} \mathrm{Ar} /{ }^{39} \mathrm{Ar}$ constraints for the "Grande Nappe": The largest rhyolitic eruption from the Mont-Dore Massif (French Massif Central).Comptes Rendus Geosciences 349, 71-80.

Nomade, S., Scaillet, S., Pastre, J.-F., Nehlig, P., 2012. Pyroclastic chronology of the Sancy stratovolcano (Mont-Dore, French Massif Central): new high-precision ${ }^{40} \mathrm{Ar} /{ }^{39} \mathrm{Ar}$ constraints. Journal of Volcanology and Geothermal Research 225-226, 1-12.

Nomade, S., Scao, V., Guillou, H., Messager, E., Mgeladze, A., Voinchet, P., Renne, P.R., Courtin-Nomade, A., Bardintzeff, J.-M., Ferring, R., Lordkipanidze, D., 2016. New ${ }^{40} \mathrm{Ar} /{ }^{39} \mathrm{Ar}$, unspiked K/Ar and geochemical constraints on the Pleistocene magmatism of the Samtskhe-Javakheti highlands (Republic of Georgia). Quaternary International 395, 45-59.

Palombo, M.R., 2014. Deconstructing mammal dispersals and faunal dynamics in SW Europe during the Quaternary. Quaternary Science Reviews 96, 50-71.

Palombo, M.R., Sardella, R., 2007. Biochronology and biochron boundaries: a real dilemma or false problem? An example based on Pleistocene large mammalian faunas from Italy. Quaternary International 160, 30-42.

Palombo,M.R., Valli, A.M.F., 2004. Biochronology of large mammal faunas from Pliocene to Middle Pleistocene in France. Geologica. Romana 37, 145-163.

Palombo, M.R., Valli, A.M.F., Kostopoulos, D.S., Alberdi, M.T., Spassov, N., Vislobokova, I., 2006. Similarity relationships between the Pliocene to Middle Pleistocene large mammal faunas of Southern Europe from Spain to the Balkans and the North Pontic Region. Cour. Forsch.-Inst. Senckenberg 256, 329-347.

Paquette, J.-L., Médard, E., Francomme, J.E., Bachèlery, P., Hénot, J.-M., 2019. LA-ICP-MS $\mathrm{U} / \mathrm{Pb}$ zircon timescale constraints of the Pleistocene latest magmatic activity in the Sancy stratovolcano (French Massif Central). Journal of Volcanology and Geothermal Research 374, 52-61. 
Paquette, J.-L., Piro, J.-L., Devidal, J.-L., Bosse, V., Didier, A., Sannac, S., Abdelnour, Y., 2014. Sensitivity enhancement in LA-ICP-MS by $\mathrm{N}_{2}$ addition to carrier gas: application to radiometric dating of U-Th-bearing minerals. Agilent ICP-MS Journal 58, 4-5.

Pareto, L., 1865. Note sur les subdivisions que l'on pourrait établir dans les terrains tertiaires de l'Apennin septentrional. Bulletin de la Société Géologique de France 22, 210-277.

Pastre, J.-F., 1987. Les formations plio-quaternaires du Bassin de l'Allier et le volcanisme régional (Massif Central, France). PhD thesis, Université Pierre et Marie Curie, Paris, 706 pp.

Pastre, J.-F., Cantagrel, J.-M., 2001. Téphrostratigraphie du Mont Dore (Massif Central, France). Quaternaire 12 (4), 249-267.

Pastre, J.-F., Debard, E., Nomade, S., Guillou, H., Faure, M., Guérin, C., Delson, E., 2015. Nouvelles données géologiques et téphrochronologiques sur le gisement paléontologique du maar de Senèze (Pléistocène inférieur, Massif Central, France). Quaternaire 26(3), 225-244.

Prévot, M., 1975. Magnétisme et minéralogie magnétique de roches Néogènes et Quaternaires, contribution au paléomagnétisme et à la géologie du Velay. $\mathrm{PhD}$ thesis, Université Pierre et Marie Curie Paris VI.

Renne, P.R., Balco, G., Ludwig, K.R., Mundil, R., Min, K., 2011. Response to the comment by W.H. Schwarz et al. on "Joint determination of $40 \mathrm{~K}$ decay constants and ${ }^{40} \mathrm{Ar} * /{ }^{40} \mathrm{~K}$ for the Fish Canyon sanidine standard, and improved accuracy for ${ }^{40} \mathrm{Ar} /{ }^{39} \mathrm{Ar}$ geochronology" by PR Renne, et al. (2010). Geochimica et Cosmochimica Acta 75, 5097-5100.

Raynal, J.-P., Magoga L., Bindon, P., 1995. Téphrofacts and the first human occupation of the French Massif Central. in The Earliest occupation of Europe, W. Roebroeks \& T. van Kolfschoten Ed., University of Leiden, 129-146.

Roger, S., Coulon, C., Thouveny, N., Féraud, G., Van Velzen, A., Fauquette, S., Cochemé, J.J., Prévot, M., Verosub, K.L., 2000. ${ }^{40} \mathrm{Ar} /{ }^{39} \mathrm{Ar}$ dating of a tephra layer in the Pliocene Senèze maar lacustrine sequence (French Massif Central): constraint on the age of the Réunion-Matuyama transition and implication on paleoenvironmental archives. Earth and Planetary Science Letter 138, 431-440. 
Rook, L., Martínez-Navarro, B., 2010. Villafranchian: The long story of a Plio-Pleistocene European large mammal biochronologic unit. Quaternary International 219, 134-144.

Sakata, S., 2018. A practical method for calculating the U-Pb age of Quaternary zircon: corrections for common $\mathrm{Pb}$ and initial disequilibria. Geochemical Journal 52, 1-6.

Sakata, S., Hirakawa, S., Iwano, H., Danhara, T., Guillong, M., Hirata, T.,2017. A new approach for constraining the magnitude of initial disequilibrium in Quaternary zircons by coupled uranium and thorium decay series dating. Quaternary Geochronology 38, 1-12.

Schärer, U., 1984. The effect of initial ${ }^{230}$ Th disequilibrium on young U-Pb ages: the Makalu case. Himalaya. Earth Planet. Sci. Lett., 67, 191-204.

Schaub, S., 1943. Die oberpliocäne Säugetierfauna von Senèze (Haute-Loire) und ihre verbreitungs geschichtliche Stellung. Eclogae Geologicae Helvetiae 36(2), 270-289.

Séguy, R., 1974. Nouvel horizon fossilifère dans le Villafranchien de la Haute-Loire. Comptes Rendus Annuels de l'Association de Paléontologie et de Préhistoire du Musée de Lyon: 79-80.

Shackleton, N.J., Backman, J., Zimmerman, H., Kent, D.V., Hall, M.A., Roberts, D.G., Schnitker, D., Baldauf, J.G., Desprairies, A., Homrighausen, R., Huddleston, P., Keene, J.B., Kaltenback, A.J., Krumsiek, K.A., Morton, A.C., Murray, J.W., Westberg-Smith, J., 1984. Oxygen isotope calibration of the onset of ice-rafting and history of glaciation in the North Atlantic region. Nature 307(5952), 620623.

Sinusìa, C., Pueya, E.L., Azanza, B., Pocoví, A., 2004. Datación magnetoestratigráca del yacimiento paleontológico de la Puebla de Valverde (Teruel). Geotemas 6(4), 339-342.

Tera, F., Wasserburg, G.J., 1972. U-Th-Pb systematics in three Apollo 14 basalts and the problem of initial $\mathrm{Pb}$ in lunar rocks. Earth and Planetary Science Letters, 14, 281-304.

Thouveny, N., 1983. Etude paléomagnétique de formations du Plio-pléistocène et de l'Holocène du Massif Central et de ses abords. Contribution à la chronologie du quaternaire. PhD thesis, Université Aix-Marseille II, Marseille. 
Thouveny, N., Taieb, M., Bonnet, A., 1984. Etude magnétostratigraphique du remplissage du Pléistocene inférieur de la grotte de La Sartanette (Remoulins, Gard). Bulletin de la Société Géologique de France 26(6), 1385-1388.

Valli, A.M.F., Caron, J.-B., Debard, E., Guérin, C., Pastre, J.-F., Argant, J, 2006. Le gisement paléontologique villafranchien terminal de Peyrolles (Issoire, Puy-de-Dôme, France): résultats de nouvelles prospections. Geodiversitas 28(2), 297-317.

van Achterbergh, E., Ryan, C.G., Jackson, S.E., Griffin, W.L., 2001. Data reduction software for LA-ICP-MS: appendix. in P.J. Sylvester (Ed.), Laser Ablation-ICP-mass spectrometry in the Earth Sciences: principles and applications, MAC Short Courses Series, Ottawa, Ontario, Canada: 239-243.

von Quadt, A., Gakkhofer, D., Guillong, M., Peytcheva, I., Waelle, M., Sakata, S., 2014. U-Pb dating of CA/non-CA treated zircons by LA-ICP-MS and CA-TIMS techniques: impact for their geologic interpretation. Journal of Analytical Atomic Spectrometry, 29, 1618.

Wendt, I., Carl, C., 1985. U/Pb dating of discordant 0.1 Ma old secondary minerals. Earth Planet. Sci. Lett., 73, 278-284.

Wiedenbeck, M., Allé, P., Corfu, F., Griffin, W.L., Meier, M., Oberli, F., von Quadt, A., Roddick, J.C., Spiegel, W., 1995. Three natural zircon standards for U-Th-Pb, Lu-Hf, trace element and REE analyses. Geostandards Newsletter19, 1-23.

\section{Figure Captions:}

Figure 1. Simplified geological map of the investigated area, redrawn from BRGM 1/50 000 maps (Girod et al. 1979; Lasnier et al. 1981; Ledru et al. 1994; Marchand et al. 1986). The Paleozoic basement is partly covered by basanitic lava flows and pyroclasts belonging to the Devès volcanic field. Dashed circles are known maar structures, including the "Fressanges maar" (Vazeilles site, Séguy 1974) which was not known at the time the geological maps were drawn. Fossiliferous sites are contained within clastic sediments or slope deposits. 
Figure 2. Cross-section of the Vazeilles deposits along the N102 road, redrawn from Séguy (1974).

Figure 3. $\mathrm{U} / \mathrm{Pb}$ diagrams for the investigated zircons from Chilhac and Mont Coupet fossils deposits. (a) and (b) are bulk sediments from the Chilhac deposits, (c) is the upper trachytic airfall located $10 \mathrm{~m}$ above the Chilhac III deposit, and (d) are slope deposits from Mont Coupet.

Figure 4. U/Pb diagrams for the investigated zircons from Senèze, Blassac-La Girondie and Vazeilles fossils deposits.

Figure 5. Older ages measured in pre-Cenozoic zircons from the fossiliferous sediments a) The TeraWasserburg plot represents the Proterozoic and Phanerozoic ages; the Concordia diagram in inset shows the Archean ages; b) Cumulative probability ages histogram plot.

Figure 6: comparison of our new ages with existing ages for the Senèze and Chilhac deposits, European land mammal zones, paleomagnetic chrons, and oxygen isotope variations. U/Pb ages from this study, Ar/Ar ages from Nomade et al. (2014b) and Roger et al. (2000). Red circles are ages of fossiliferous sediments, white triangles ages of tephra-bearing layers above (down-pointing) or below (up-pointing) fossiliferous sediments, and squares for non-fossiliferous sediments or tephra-bearing layers disconnected from the fossil deposits. 
890 Table 1. Comparative list of large mammals described in the five investigated fossil deposits. The 891 Chilhac list is reproduced from the compilation of Boivin et al. (2010), the Coupet list from Heintz 892 (1974), the Senèze list from the work of Delson et al. (2006), the Blassac list from Beden and Guth 893 (1970b) and Boeuf et al. (1992), and the Vazeilles list from Séguy (1974).

895 Table 2. Sample location and U/Pb chronological data for the investigated fossil sites.

897 Table 3. Zircon U-Th-Pb data from the dated samples obtained by in situ Laser-Ablation-ICP-MS. 